This PDF is a selection from a published volume from the National Bureau of Economic Research

Volume Title: Law and Employment: Lessons from Latin American and the Caribbean

Volume Author/Editor: James J. Heckman and Carmen Pagés, editors

Volume Publisher: University of Chicago Press

Volume ISBN: 0-226-32282-3

Volume URL: http://www.nber.org/books/heck04-1

Conference Date: November 16-17, 2000

Publication Date: August 2004

Title: Unions and Employment in Uruguay

Author: Adriana Cassoni, Steven G. Allen, Gaston J. Labadie

URL: http://www.nber.org/chapters/c10075 


\section{Unions and Employment in Uruguay}

Adriana Cassoni, Steven G. Allen, and

Gaston J. Labadie

\subsection{Introduction}

The subject of how unions affect employment adjustment generates strong opinions. The prevailing view among many economists and policy analysts is that unions prevent labor market forces from operating effectively. Unions take a hard line in bargaining that prevents wages from falling, no matter how high unemployment has gotten. They resist attempts by management to streamline production and introduce new technology. They stand in the way of team-based production by clinging to outdated job descriptions and occupational jurisdictions. They insist on advance notice and severance pay arrangements that make it extremely costly to reduce employment.

$A u$ contraire, say union supporters. Centralized negotiations provide a framework for wage adjustments to take place more rapidly than they would in a world where all bargaining is one-on-one. Unions see the handwriting of technological change on the wall as clearly as management and also see that management does not think about implementation of new technology in the workplace until installation time. Joint committees provide a framework to make changes more productive by getting full input from employees on how to redesign jobs and processes. Rules on job security admittedly make downsizing more difficult, but other parts of union agreements make labor markets more effective by encouraging long-term employment relationships and investments in firm-specific skills.

Adriana Cassoni is professor of economics at the University of Uruguay. Steven G. Allen is professor of economics and business management at North Carolina State University, and a research associate of the National Bureau of Economic Research. Gaston J. Labadie is dean of the faculty of administration and social sciences at the Universidad ORT Uruguay. 
In Latin America, the prevailing wisdom is that the former view is closest to the truth. Even though most markets have been liberalized, the labor market has been what Sebastian Edwards, the former chief economist for Latin America and the Caribbean at the World Bank, calls "the forgotten sector" (1995, 277). Welfare losses come from three main sources: (1) wages set above market clearing levels, (2) lost output and wages from strikes, and (3) rent-seeking activities such as support for protectionism and state ownership of industry. Edwards $(1995,286)$ argues

Reforming legislation governing labor-management relations in Latin America is an important unfinished part of the recent structural reforms. In general, a modern and flexible legislation is characterized by incentives to resolve conflicts quickly and fairly. This requires clear rules of the game, modern institutions, an efficient judiciary, and a system in which both parties incur costs if the conflict becomes protracted. In most countries, however, the current situation is far from that: there are asymmetric costs for unions and employers that, in fact, do not penalize delaying agreements.

Given these very strong views, one would think that there would be a massive research literature on how unions affect employment adjustment to changes in wages and output. Think again. Globally this subject has received little attention, and in Latin America it has received virtually no attention. In the case of Uruguay, some theoretical work has been developed by Rama (1993a,b, 1994), while there is some recent empirical research (Allen, Cassoni, and Labadie 1994, 1996; Cassoni, Labadie, and Allen 1995). Although there are numerous studies making union-nonunion comparisons for particular countries at particular time periods, they have generally concentrated on wage gains and wage gaps (Blanchflower 1984; Freeman and Medoff 1984; Hirsch and Addison 1986; Lewis 1986, 1990) while employment differentials have been somehow neglected. ${ }^{1}$ Regarding elasticities of substitution between labor and capital and among different types of labor, research has been even less prolific. In the United States, it has been found that they are much lower in union than nonunion establishments (Allen 1986; Freeman and Medoff 1982). Further, Boal and Pencavel (1994) found some evidence suggesting the underlying production function is different, depending on the sector's being unionized or not. In the United Kingdom, Blanchflower, Millward, and Oswald (1991) analyzed the impact of unionism on the path of employment growth, finding significant differences, although their result has been criticized for not being robust (Machin and Wadhwani 1991).

Another line of research that has been followed is that related to the influence of unions on the costs of adjusting the level of employment (Burgess 1988, 1989; Burgess and Dolado 1989; Hamermesh 1993; and Lockwood and Manning 1989 are examples). Finally, it has been found that

1. An extensive survey can be found in Pencavel (1991) and Booth (1995). 
workers in the United States have lower quit rates (Freeman 1980), higher layoff rates in the private sector (Medoff 1979), and lower layoff rates in the public sector (Allen 1988), relative to nonunion workers.

Although all of the previous papers do illuminate one component or another of the effects of unions on wages and/or employment, they do not address the bottom-line questions. For the same establishment or individual with and without union status, does employment adjustment to changes in wages and output vary when the firm is unionized and when it is not? How long does it take to complete the adjustment in these two settings?

This chapter examines these issues directly, using evidence from manufacturing industries in Uruguay from 1975 through 1997. Uruguay is well suited for such a study because the economy has gone through a series of regime changes. A military government took over in 1973 and stayed in power through 1984. During and after this regime, there were significant changes in labor and trade policy that will allow us to identify the impact of these policies on labor demand parameters.

Collective bargaining was proscribed during the military regime, but labor unions regained the right to bargain collectively with the return of democracy in 1985. As part of its anti-inflation policy, the national government played a significant role in negotiations. Since then, legal regulations of work - which constitute public-order individual rights and therefore cannot be resigned under any circumstance - can be superseded by collective agreements. They can go beyond these restrictions, increasing (but not decreasing) the benefits that workers have in the area of minimum wages, working conditions, job security, and employee benefits. Tripartite negotiations took place at the industry level through "Wage Councils," allowing wage adjustment to vary by industry. If an agreement met the government's anti-inflation targets, then it would apply to all firms in the industry - even those with nonunion work forces - once the agreement was officially endorsed.

The government stopped participating in this system in 1991. Some bargaining is still conducted through industry-wide Wage Councils, but increasingly it is being done at the company level. As a result there are three different bargaining regimes that can be examined in this study: (1) before 1985, when bargaining was banned; (2) 1985-1991, when there was tripartite bargaining; and (3) 1992 to the present, when the government did not participate in bargaining.

Although the primary focus of this study is on the impact of these regime changes, the role of changes in trade policy cannot be ignored. Taxes on traditional exports were substantially cut in the mid-1970s, and some initial steps were taken toward lowering import barriers, steps that halted during the global recession of 1982. After a temporary increase in 1985, tariffs were gradually decreased starting in 1986. By the end of 1993, the highest tariff was 20 percent. At the same time, there were reductions in nontariff barriers, elimination of some sectoral privileges, and reductions 
of export subsidies. Accompanying these unilateral policy changes was the creation of the Southern Cone Common Market (MERCOSUR) in 1991. By 1995 a great number of Uruguayan products could be exchanged with MERCOSUR members (Argentina, Brazil, and Paraguay) without any tariff. As a consequence, there was a sizable increase in the volume of both exports and imports that, as will be shown in the following, had a significant impact on union behavior.

This study looks at two types of evidence. The primary focus is on estimating labor demand parameters under different bargaining regimes. Using standard techniques, the elasticity of employment to wages and output is estimated and compared across policy regimes. The model is then extended to examine the dynamics of the adjustment process. A dynamic labor demand model is estimated, letting the length of the lag vary with the extent of openness and with the percentage of workers covered by collective bargaining. Additionally, the odds of layoffs and turnover resulting in unemployment are examined to further understand the microprocesses by which unions have an effect on the adjustment process.

The chapter begins with background on the economy, the labor market, and collective bargaining in Uruguay (section 8.2), followed by a brief theoretical overview on unions and labor demand (section 8.3) and a description of the data (section 8.4). The labor demand results (section 8.5) indicate that a structural shift in the labor demand function occurred at about the same time as the return of collective bargaining. Wages are weakly exogenous to employment through 1984, but weak exogeneity is rejected afterward. The elasticity of employment to wages and output fell by more than 50 percent after 1984. There is no change in the amount of time needed for the market to adjust, as indicated by the coefficient of lagged employment. Results from a bargaining model show that union wage demands are highly sensitive to the openness of the economy. These patterns are further analyzed in the dynamic and in the mobility and unemployment results (section 8.6). The concluding section summarizes and assesses these findings.

\subsection{Background on Uruguay}

\subsubsection{Macroeconomic and Labor Market Conditions}

Traditionally, the Uruguayan economy has been subjected to a series of global and regional shocks, particularly those coming from Argentina (Favaro and Sapelli 1986), and this has continued during the last twentyfive years. At the beginning of the sample period (1975), the Uruguayan economy was still recovering from the oil shock of 1973 and the ensuing global recession. These conditions were exacerbated by the European Community's decision in 1974 to stop importing beef. Unemployment was above 10 percent in 1976-1978 (see figure 8.1). 


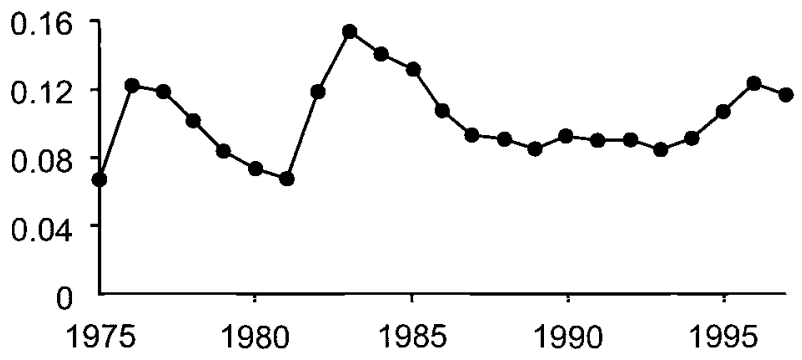

Fig. 8.1 Unemployment rate

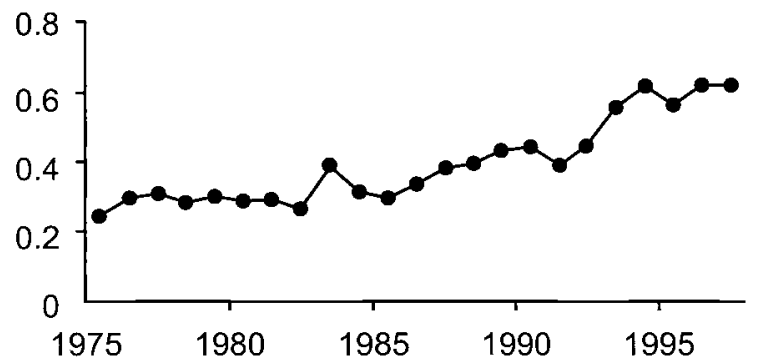

Fig. 8.2 Openness

The economy recovered in the late 1970s in response to a series of steps to liberalize financial markets and promote exports. Growth accelerated when the government adopted a preannounced schedule of monthly devaluations, with the rate of devaluation declining gradually over time. Global economic conditions, however, were not kind to this schedule; by the early 1980s, the net result was a highly overvalued currency that had to be devalued in the global recession of 1982. Unemployment had fallen to 7 percent by 1980-1981 but increased to 15 percent in 1983 and stayed above 10 percent through 1986. The gross domestic product (GDP) decreased by 15.9 percent in three years.

By 1988 Uruguay had successfully recovered from this deep recession. The economy grew 8.9 percent in 1986 and 7.9 percent in 1987, supported by an increase in demand from Brazil, which was implementing a stabilization plan (Plan Cruzado). Exports grew and the public deficit decreased to 4.2 percent of GDP in 1987. In 1989, however, the favorable regional environment changed, the public sector deficit grew to 7 percent, and a stabilization plan was implemented by the new government (elected in 1990). These policies have resulted in a sustained, steady decline in inflation from 129 percent in 1991 to 15 percent in 1997.

During the 1990s, together with the regional shocks, a domestic stabilization plan and an increase in the openness of the economy had significant effects on macro and industry performance (as shown in figure 8.2, 
where openness is defined as the ratio of imports plus exports to GDP). The Argentinian "Plan de Convertibilidad," imposed in April 1991, improved relative competitiveness for Uruguay, with exports to that country increasing 130 percent in 1991 and 74.3 percent in 1992. Expanded trade with Argentina, no small part of which consisted of tourism, and a deterioration of the real exchange rate meant that growth in the service sector far outstripped growth in goods production. Within the latter, the actual impact depended upon exposure to external competition.

Besides the domestic stabilization plan, during the period 1990-1992 a series of trade policy measures consolidated the opening of the economy that had started in the mid-1970s during the military regime, but that was discontinued in the early 1980s. In 1982, the highest tariff was 55 percent and after a temporary increase in 1985, a gradual decrease started in 1986, which ended with a maximum tariff of 40 percent in 1989. The pace of these changes accelerated in 1991-1993. By 1993 the highest tariff was 20 percent. Together with these reductions, many nontariff barriers and sectoral privileges (like those given to the automotive industry) were removed, and export subsidies were reduced (de Brun and Labadie 1997).

These unilateral trade policy changes were accompanied by a series of regional tariff reductions as a consequence of the creation of the MERCOSUR. By 1995 a great number of Uruguayan products could circulate among its members, Argentina, Brazil, Paraguay, and Uruguay, without any tariff. The exceptions to the Common External Tariff are subject to a calendar that was established in December 1994. Economic conditions deteriorated after 1994, largely in response to high unemployment generated by the "tequila effect" in Argentina. Unemployment increased to 11 percent in 1995 and 12 percent in 1996-1997. Unemployment held steady at around 9 percent between 1987 and 1994.

The manufacturing sector has been severely affected by all of these factors. Its share in total output has gone down from 25-27 percent at the beginning of the period to 18 percent in 1997. Employment in manufacturing grew until 1989, but it has decreased significantly since then, to unprecedented levels. This decrease reflects the impact of trade liberalization as some establishments cut back production, whereas others raised productivity to compete.

\subsubsection{Collective Bargaining}

When Parliament was closed by the military in June 1973, the union confederation Convención National de Trabajadores (CNT) launched a general strike. The government reacted by banning union activity and giving employers the right to dismiss anyone who did not return to work. Many union leaders were jailed; the others went into hiding or exile. The union movement began a political comeback in the early 1980s, with a series of 
demonstrations and general strikes organized by a new confederation, but there was no bargaining until the return of democracy in $1985 .^{2}$

In the absence of unions, employers were relatively free to adjust wages and employment. Wage increases were limited to lagged inflation. This policy, along with high unemployment, was accompanied by a 49 percent decrease in real wages from 1973 through 1984. Employment adjustment also became more flexible. Interview evidence compiled by Handelman (1981) indicates that after the ban on unions, many employers used the opportunity to get rid of trade union officials and excess employees. Dismissals of public-sector workers also were permitted by law between 1977 and 1984 (Gillespie 1991). On the supply side, there was a surge in emigration precipitated by political repression and high unemployment. Taking into account all of these factors, it is clear that the Uruguayan labor market was exposed to strong competitive forces during the ban on unions.

Starting in 1985, Uruguay's unique system of Wage Councils was reinstituted. Collective bargaining in the private sector in Uruguay had traditionally operated mainly through a system of trilateral Wage Councils that set minimum wages by industry and labor category. Wage levels were adjusted three times per year through 1990; since then, accumulated inflation since the last adjustment had to pass a specific threshold for wages to be adjusted. Often, the Wage Councils agreed to a formula that would be in effect for sixteen to twenty-four months, allowing adjustment to take place without a formal meeting. If the government delegates gave their consent to the wage agreement, it applied to the entire sector, not just to the firms and unions involved in the bargaining. Government approval usually required keeping wage increases in line with official inflation targets. Direct negotiation between the union and the firm was also practiced, especially in manufacturing. In 1991 there was a significant change in the structure of negotiations. The government stopped participating in bargaining, and the terms of the contract became binding only on those firms and unions that were actually represented in the negotiation. Currently, Wage Councils meet in only a few sectors and the result, to be shown in the following, has been a sharp drop in union density in the private sector.

Much bargaining now takes place at the company level. Membership is not compulsory and union dues are voluntary in most cases. In 1988, only three years after unions were legal again, the single National Central Union reported a total of 188,000 members and five years later, in 1993, 177,000 members, belonging to seventeen federations and 359 unions. In 1996, there were 164,000 members in the National Central Union, but some unions are not members of it. By 1993, 54 percent of the membership

2. For a general description of labor market institutions in Uruguay, see Cassoni, Labadie, and Allen (1995). 
belonged to the public sector, which has had the smallest drop in its number of affiliates.

The role that collective agreements play in introducing rigidities could be very significant, varying in degree depending on union density and the specific clauses of the contracts, which include wage adjustments, minimum wages by job categories, length of work day, holidays, job rotation and stability, recognition of union officers, "peace clauses" that preclude strikes under certain circumstances, and other work-related conditions. Although there are no explicit clauses regarding severance pay or restrictions to hiring new workers, unions have generally imposed extra costs to employment adjustment. In some sectors, additional compensation beyond that dictated by the labor contract has been a common practice, while in others strikes have worked as a means of getting additional severance pay. Government intervention in collective bargaining is only provided in the case of Wage Councils, and there is no other regulation of the bargaining process, not even in the case of conflict and strikes (for a more detailed description, see Cassoni, Labadie, and Allen 1995, 167-70). No database up to this date has actually evaluated the impact of the contents of collective agreements. Recently, Cedrola, Raso, and Perez Tabó (1998) have examined qualitatively the contents of collective agreements for the period 1985-1995. For this study, a database that covers all collective agreements registered at the Ministry of Labor between 1985 and 1997 has been developed, and the contents of its clauses have been quantified to determine the actual nonwage costs resulting from the bargaining process at the industry level.

Using these data it is possible to analyze quantitatively a period in which union behavior was absent (through 1984); a period in which we know the union density of the sector as well as the amount of nonwage costs imposed on all firms in an industry, a consequence of a bargaining structure in place from 1985 through 1991; and a more recent period in which we know union density, but the collective agreements are exclusively binding for those firms and those workers that participated in the negotiation and signed the agreement. The completeness of data for this final period is less clear, because many of these agreements did not have to be registered at the Ministry of Labor (precisely because they did not have to be endorsed by the public authority in order to be binding among the contracting parties).

This study focuses on manufacturing, where there are pronounced changes in union density during the last decade, with no small amount of variation across individual industries. Upon the return of unions in 1985, 60 percent of production workers were covered by collective-bargaining agreements (see figure 8.3).

This initial level probably reflects political support for the role unions played in the return to democracy. Union sustainability hinges on both worker support for collective, as opposed to individual, agreements, and 


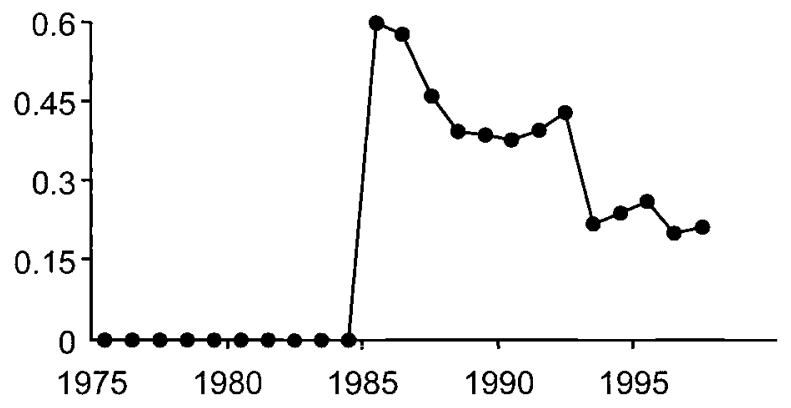

Fig. 8.3 Percentage union

Table 8.1 Percentage Union and Openness Ratio, by Year and Industry

\begin{tabular}{lrrrrrrrrr}
\hline & \multicolumn{4}{c}{ Union } & & \multicolumn{3}{c}{ Open } \\
\cline { 2 - 3 } Industry & 1985 & 1988 & 1992 & 1997 & & 1985 & 1992 & 1997 \\
\hline Food products & 59 & 54 & 55 & 27 & & 24 & 24 & 28 \\
Textiles and apparel & 77 & 54 & 46 & 16 & & 49 & 54 & 83 \\
Paper products & 70 & 52 & 44 & 39 & & 19 & 19 & 45 \\
Chemicals & 100 & 87 & 100 & 94 & & 16 & 44 & 60 \\
Nonmetallic & 48 & 21 & 11 & 10 & & 12 & 22 & 36 \\
Metal products & 100 & 43 & 43 & 19 & & 76 & 146 & 350 \\
\hline
\end{tabular}

on the ability of unionized employers to survive economically. Union density gradually dropped to 40 percent by 1988 and stayed near that level through 1992. By this point the contracts signed under the old Wage Council system had expired, and the impact of trade liberalization was beginning to be felt. The openness ratio jumped from 44 percent in 1992 to 55 percent in 1993 and was above 60 percent for most of 1994-1997. Union density dropped from 42 percent in 1992 to 22 percent in 1993 and has stayed at about that level since. The pattern of union growth and decline has varied considerably across industries, as shown in table 8.1.

Union strength remained near 100 percent throughout the sample period in the chemical and oil industries, which not coincidentally consist largely of state-owned enterprises. In fact, union density dropped in all industries after 1992, except in chemicals and oil products. The most dramatic decline took place in metal products and nonmetallic industries, where union coverage in the period dropped to 20 percent of its original level. At the same time, and particularly in metal products, imports plus exports increased sharply. There also was a considerable drop in union coverage in textiles and apparel and, to a lesser extent, in the paper industry. With the exception of food products, all industries experienced an increase in openness after 1992. 


\subsection{Theoretical Framework}

This section describes the framework used to analyze possible changes in both elasticities of labor demand and labor dynamics, due to the institutional changes that took place in 1985, that is, the reappearance of trade unions as "players" in the labor market. In order to do so, the estimable models will be specified so as to measure labor demand elasticities for production workers and the speed of adjustment of labor to its equilibrium level in both regimes.

Through 1984, a competitive model seems suitable to describe the behavior of the labor market. Wage increases were set by the government from 1968 up to 1979, although from 1977 onward there were extra shifts in some sectors. The government concerns in this process were focused on stopping the huge increase in inflation rates so that it decided to "freeze" all prices and wages in the economy, not taking into account labor demand conditions. Hence, they were exogenous to the firm. Since 1985, it might be possible to approximate the observed employment and wage pairs using the same model, but the institutional framework actually changed. Since that date, the wage level has been the result of a bargaining process that has, itself, evolved all along the decade. Before 1992, bargaining was a synchronized process, taking place at the industrial-sector level through Wage Councils. After that date, it became more heterogeneous as negotiations at the firm level have become quite common, while synchronization has deteriorated.

Given the previously mentioned institutional changes, the following research strategy was developed: First, a model of labor demand derived from a pure neoclassical static framework was estimated. The wage variable is a cost of labor proxy, including wage plus nonwage costs - such as health insurance and payroll taxes - as well as other benefits bargained between firms and unions from 1985 onward.

As will be shown in more detail in the following, the model was estimated for the whole period and the stability of the parameters was tested. The econometric analysis supported the specification of a different model for the post-1984 period. This model was derived from a bargaining framework. A first implication is that wages are not exogenous as in the previous specification, as they are determined jointly by unions and firms through a bargaining process, where firms attempt to maximize profits and unions maximize their members' utility function. Second, other variables could enter the model as alternative wages or fallback positions of the parties.

\subsubsection{Labor Demand: Theoretical Framework}

We begin with a standard specification for a labor demand equation in a static framework. Assuming a generalized constant elasticity of substitution (CES) production function with three inputs (capital and labor di- 
vided in production and nonproduction workers), maximization of profits would yield a three-equations system of derived demands for each input. The equation describing the demand for production workers would be

$$
\ln N_{t}=\alpha_{0}+\alpha_{1} \ln \left(\frac{w}{p}\right)_{t}+\alpha_{2} \ln Q_{t},
$$

where $N=$ employment of production workers, $w=$ wage, $p=$ product price, and $Q=$ output.

Hence, the elasticity of substitution between capital and employment $(\sigma)$ is equal to $-\alpha_{1}$, while the wage elasticity of labor demand is $-\alpha_{1} \cdot(1-$ $\mathrm{s}_{\mathrm{L}}$ ), with $\mathrm{s}_{\mathrm{L}}$ denoting labor share in value added.

In order to estimate the model, some methodological issues have to be resolved. If variables are not stationary, a possible strategy is to estimate the model in differences. A second approach would be to test if the variables involved are cointegrated and, if so, if the estimation can be carried out in levels. Because the estimators in equation (1) are biased in finite samples, it might be preferable to estimate a dynamic version of the model based on Engle and Granger's representation theorem (Engle and Granger 1987):

$$
\alpha(L)(1-L) \mathbf{Z}_{t}=-\gamma \beta \mathbf{Z}_{t-1} d(L) \varepsilon_{t},
$$

where $\alpha(L)$ is a polynomial matrix in the lag operator; $\mathbf{Z}$ denotes the vector of variables involved $(N, w / p, Q) ; d(L)$ is a polynomial; and $\varepsilon_{t}$ is a stationary process.

The model can be linearly transformed as an autoregressive-distributed lag model:

$$
\alpha_{1}(L) y_{t}=\alpha_{2}(L) \mathbf{X}_{t}+\varepsilon_{t},
$$

where $\alpha_{1}(L)=1-\sum_{i=1}^{m} \alpha_{1 i} L_{i} ; \alpha_{2}(L)=\sum_{i=0}^{m} \alpha_{2 i} L_{i}$ and $(y, \mathbf{X})=\mathbf{Z}$.

The econometric analysis of the model will determine its final dynamic structure. It has been shown that the lag structure of each variable need not be the same (for an extensive discussion of all the above methodological issues, see Banerjee et al. 1993).

The fact that variables are nonstationary means that at least some shocks have permanent effects on them. In particular, shocks related to productivity and accumulated knowledge have been generally found to be nontransitory so that they have long-lasting effects on output and employment (Aghion and Saint-Paul 1993; Blanchard and Quah 1989; and references therein). Thus, variables would have a stochastic trend, but, if cointegrated, the equilibrium relationship among them would still be stationary and hence stable. The dynamics are the result of agents not being able to adjust instantaneously to equilibrium because of factors such as adjustment costs, price rigidities, and so on. Adjustment costs have been extensively discussed in the literature (Hamermesh 1993, 1995; Hamermesh and Pfann 1996) as the source of the observed lags in adjusting em- 
ployment. They would explain why actual employment $(N)$ differs from its equilibrium level $\left(N^{e}\right)$. If firms maximize expected profits, expectations are static and costs are quadratic, the optimum path of employment would be

$$
N_{t}=g\left(N^{e}-N_{t}\right),
$$

yielding a demand for labor equation like

$$
N_{t}=\lambda N_{t-1}+\beta \mathbf{X}_{t},
$$

with $\mathbf{X}_{t}$ being a vector of variables determining long run labor demand and $\lambda$ a parameter measuring the speed of adjustment to equilibrium, which is thus assumed to be constant.

\subsubsection{Bargaining Models}

Since 1985 unions started playing a role in the determination of wages, working conditions, and employment. Their role has varied over time, as well as the issues they bargained over. After analyzing all the collective agreements that have been signed since then, it is clear that there have always been negotiations over wages but rarely over employment. Agreements have covered a wide range of other benefits, increasing the annual wage a worker receives; linking the wage to different variables, such as productivity or tenure; and increasing fringe benefits. Working conditions have also been in the bargaining agenda, as well as the length of the working week and year. Although at first glance negotiations looked as if done in stages, this turned out to be false. The procedure followed has generally been one by which at some point unions and firms have bargained over the wage, other benefits, and working conditions. Regarding every issue but the wage, agreements have worked as long-term contracts (one year minimum, three years on average). Regarding the wage, however, they were quite short, covering a time period of three or four months, so that most of the contracts were agreements only over the wage.

The foregoing suggests that the most suitable benchmark to analyze the Uruguayan bargaining process is that of a right-to-manage model (for a discussion on this topic, see Pencavel 1991). The model will be considered as a maintained hypothesis, based on the analysis of all collective agreements. No tests against an efficient contract model will be carried out as it has been extensively proven by now that those tests cannot support one specification against the other (Booth 1995; Pencavel 1991). ${ }^{3}$ Thus, the following specification is used:

3. For example, the alternative income would enter the employment equation only in the efficient contract model. However, some utility functions can yield a solution to the efficient bargain that excludes the alternative income from the specification. Further, the empirical distinction between both models is not straightforward, as the contract curve may lie on the labor demand curve (Carruth and Oswald 1987). Given the model proposed, we are explicitly assuming that unions have no direct impact on employment. However, we did perform the exercise of adding union variables to the employment equation, and the estimation results supported the model specified. The output of these regressions is available upon request. 


\section{First Stage: Unions and Firms Bargain over the Cost of Labor}

$\Gamma\left(w, w_{a}, N\right)$ is the union's utility function, where $w$ is the real wage, $w_{a}$ is the alternative income, and $N$ is employment. It is assumed that membership status is lost if unemployed; that all members of the union are equally considered by union leaders; and that members care about the real wage surplus over the alternative income they would earn working elsewhere or being unemployed (de Menil 1971). A standard specification is then

$$
\Gamma\left(w, w_{a}, N, M\right)=\left(w-w_{a}\right) N^{\phi},
$$

where $\phi$ is a parameter denoting how much weight the union gives to employment in its utility function. If $\phi$ equals 1 , then the model is the rentmaximization model (Pencavel 1991).

$\Pi\left(p, Q, K, N, p_{c}, w\right)$ is the firm's profit function, where $K=$ capital and $p_{c}=$ price of $K$. It is assumed that managers maximize revenue minus costs, so that

$$
\Pi\left(p, Q, K, N, p_{c}, w\right)=p Q-w N-p_{c} K .
$$

A well known solution to the bargaining problem is given by the maximization over the wage of the generalized Nash bargain, subject to the optimum labor demand that will be set in a second stage:

$$
\begin{gathered}
\operatorname{Max}_{w} Y=\left(\Gamma-\Gamma_{0}\right)^{\beta}\left(\Pi-\Pi_{0}\right)^{1-\beta} \\
\text { s.t. } \\
N=N^{*}
\end{gathered}
$$

$\Gamma_{0}$ and $\Pi_{0}$ are the fallback positions of each player. They refer to what the union and the firm would get in the event of no agreement (Binmore, Rubinstein, and Wolinski 1986). If we assume that under this circumstance there will be a strike, then the firm will have zero operating profits, and union members will have zero earnings. ${ }^{4}$

Second Stage: Firms Maximize Profits

$$
\operatorname{Max}_{N, K} \Pi=p Q-w N-p_{c} K
$$

Subject to quite restrictive assumptions, the solution for (6) and (7) is

$$
\begin{aligned}
N^{*} & =N(w / p ; Q) \\
w^{*} & =\eta w_{a} .
\end{aligned}
$$

The first equation is just the result of profit maximization by firms, under a CES production function, for example. However, to get the equation

4. There are no legal provisions assuring any income to strikers in Uruguay. They generally ask people for contributions, but this cannot be measured. 
for the wage level, it has to be assumed that, when bargaining, firms take capital as given; that is, they have already made decisions on the capital level. Thus, the profit function depends solely on employment. The parameter $\eta$ is a markup over the alternative income. This parameter is a function of sector characteristics, such as the degree of competitiveness and the affiliation rate (Layard, Nickell, and Jackman 1991).

Finally, the alternative-income workers consider as a comparison wage is a weighted average of what they would earn if they got a job in any manufacturing industry, what they would get if they decided to become selfemployed, and what they would receive as unemployment benefits in the event of losing their jobs. Weights are given by the probability of being in each of the mentioned states, calculated as the annual frequency of each category.

The estimable model proposed is a multivariate model, in which wages are not exogenous but set subject to the determination of the level of employment. Unionism is treated as an exogenous variable because the major changes in this variable during our sample period were driven by social and political processes.

\subsubsection{Union Impact}

In a static framework, unions have an incentive to take whatever steps they can to reduce the wage elasticity of labor demand so that they can bargain for increased wages with less severe consequences for employment. Unions can make product demand less elastic by making fewer options available to consumers through various rent-seeking activities. One way of doing this is to create entry barriers, such as state ownership or regulated entry into markets where establishments are unionized. Tariffs, quotas, and other barriers to free trade also can be used to reduce consumer choice.

The elasticity of substitution between union labor and other inputs can be reduced through collective bargaining. Contracts with unions often spell out the conditions under which work is to be performed, including dictates on minimum crew sizes, limitations on substituting nonunion personnel for work that "belongs" to the union, and limits on technologies that reduce labor hours.

Empirically, it is well known (at least since Marshall) that unions should try to organize the sectors of the economy with the most inelastic demand. In this study we look at the same sectors of manufacturing before and after reunionization, so this allows us to control for this self-selection into rent-seeking opportunities. Instead, this study will be able to establish in a before-and-after framework whether unions are actually able to reduce labor demand elasticities.

The impact of unions on adjustment lags and the elasticity of labor demand to output hinge on a variety of factors. Ignoring adjustment costs for the moment, keep in mind that firms can adjust labor hours to a change in 
output by changing employment or by changing hours per person. The impact of unions on this tradeoff is not clear ex ante. Unions often negotiate for premium rates for overtime that are well above those required by labor legislation, which would by itself lead unionized firms to increase employment more for a given increase in output. However, unions also negotiate for employee benefits that make increasing employment expensive relative to increasing hours. Lower turnover in unionized establishments encourages greater investments in employee training, which in turn increase the cost of hiring an additional person. In a frictionless world, the effect of unions on the employment-hours balance would be an empirical question that would hinge on whether the marginal cost of an extra hour per person is the overtime rate dictated by labor laws or the superovertime rates from the union contract. If it is the standard overtime rate, then the dominating effect of unions would be through increased costs of hiring an extra person, and we would expect a smaller elasticity of employment to output.

A final channel for union influence is the speed at which labor adjustments are made. Unions have numerous methods at their disposal to change the cost of making changes in employment. This can be done with formal contract provisions dictating advance notice or severance pay in case of layoffs or through informal threats of slowdowns or strikes. Another factor leading to slower adjustment of employment to output in unionized establishments is the low rate of voluntary turnover. When attrition is sufficiently high, employment can adjust very quickly through a simple hiring freeze.

The expected duration of layoffs often plays an important role. If the expected duration of a drop in output is expected to be short, unions will not hesitate to opt for layoffs rather than hours reductions so that workers can take full advantage of unemployment insurance. The prevailing wisdom is that unions create longer adjustment lags through their impact on advance notice and severance pay.

\subsection{Data}

Before describing the actual definition of variables, some aggregation issues are worth stating. First, the units of observation considered will be manufacturing industries at the two-digit level of aggregation. Six of them can be observed during the period 1975 to 1997: food, beverage and tobacco; textiles and apparel; paper; chemicals and oil products; nonmetallic minerals; and metal products. It is well known that the optimum unit of observation is the establishment, as adding up technologies never guarantees that the parameters obtained for the aggregate are what they are sought to be. However, working with industries is not the worst of the alternatives. In a small country like Uruguay, most of the year-to-year variation in industry data is driven by a small number of firms; hence, problems 
related to aggregate data should be fewer than in a large country. Nevertheless, it should be taken into account that this might bias the estimates (Hamermesh 1993). Second, temporal aggregation does not seem a problem here as quarterly data will be used so that the lag structure should not understate the true lag structure.

\subsubsection{Cost of Labor: $W$}

The measure to be used in the model has to approximate the total cost of labor for the firm so that it has to include not only the wage but also nonwage costs. The latter include labor taxes; social security contributions; and bargained costs since 1985 . We are omitting, however, all costs related to hiring and firing workers. In order to account for these costs, the labor demand function should be specified, contingent on different states of nature that would imply firing or hiring workers, and a distribution of these states should be also proposed. It can be shown that not specifying a statecontingent labor demand might bias the estimates of the elasticities downward due to the omission of relevant variables. We will not address this issue empirically as data needed to calculate marginal firing and hiring costs are not available. ${ }^{5}$

Data on wages are obtained from the Quarterly and Annual Industrial Surveys carried out by the National Institute of Statistics (INE). ${ }^{6}$ Annual data for production workers are available from 1975 up to 1997. Quarterly

5. The law relative to severance pay has not changed in the sample period, and the compensation a worker is entitled to is the same for all industries and depends on his/her tenure (none if tenure is less than three months; one wage per year for those working for more than three months, up to a maximum of six). Average tenure for those employed in 1991-1997 (the only years for which the data is available) is between seven and ten years, not varying much between industries. Hence, the expected average severance pay does not change, being between 3.7 and 4.2 wages, depending on the industry. As it is not possible (due to the number of observations) to calculate the probability of a worker being laid off for each tenure, this should be calculated as the overall frequency of layoffs and will thus be negatively correlated with employment by definition. Finally, even if we included a tentative measure of average severance pay based on tenure of employees instead of on that of laid off workers, we would be introducing biases which need not be of the same sign along the period. They would depend on the prevailing rules of firing workers, and these have been probably different during 1975-1997. The only evidence available was especially collected for the last quarter of 1997. Manufacturing workers who were laid off in the month prior to the survey had an average tenure of 1.5 years, while the average for all unemployed manufacturing workers was six years. This suggests that a rule of last in-first out was in place. However, during periods of restructuring, as were the late 1970s and the early 1990s, firms might have gotten rid of more senior workers, that is, workers with higher wages and who were not easily retrainable. Given all these issues, we will omit these costs from the analysis, although they might be reflected in the estimated effect of unions on the labor demand model.

6. These surveys are carried out using a sample of firms employing five workers and more that stems from the previous industrial census. Data collected refer to many variables related to production, employment, and inputs. The Quarterly Industrial Survey reports indexes while the Annual Industrial Survey publications report values. The Wage Survey is carried out on a monthly basis at establishments belonging to all economic sectors. 
data, however, are not published (nor processed by the INE) after 1991. Hence, for 1992-1997, the within-year evolution of wages was assumed to follow the same pattern as that stemming from the Wage Survey (INE) for manufacturing workers. ${ }^{7}$

Data on nonwage costs were taken from Picardo, Daude, and Ferre (1997) and from Cassoni and Ferre (1997). All costs related to health insurance and social security as well as payroll taxes were used to build a factor by which to increase wages for each two-digit industrial sector. Social security and health insurance contributions are a fixed percentage of wages that has varied over time. On the other side, payroll taxes, first imposed in 1982, have generally varied, depending on the level of earnings. Hence, information from the Household Survey (INE) was used to calculate the distribution of workers in the different relevant segments, yearly, for each manufacturing sector. Apart from these factors increasing wages, employers face an annual extra payment of one monthly salary plus twenty days that must be paid before the worker starts his/her annual holidays before the end of the year. Both were also included in the cost of labor. There are several issues over which unions have bargained since 1985. Among them, supplemental end-of-year bonuses, either related to tenure, productivity, or simply on a general basis; shorter length of the working day; and extra holidays. These negotiations took place at the industrial two-digit level so that they vary by industry. Annual premia applying to all workers was directly used to increase the factor built upon the legal rates. Information on extra holidays was used to calculate the percentage increase in costs due to nonworking days. If paid vacations were twelve days more per year over the legal standard, the actual monthly wage would be $25 / 24$ times $w$, instead of $w$. Where agreements were reached shortening the legal length of the working day or week, the cost of labor was increased by the proportion of legal to bargained hours in the same way as paid vacations.

All the information described above, stemming from the manufacturing collective agreements signed between 1985 and 1997, was used to build an index increasing the legal cost of labor. This index varied in time and among industries, with an average value for the whole manufacturing sector of 12 percent. Industries with the lowest extraordinary bargaining costs were paper; metallic industries; and nonmetallic minerals, for which the increase was around 1 percent on average. Sectors related to food, beverage and tobacco, and chemicals have negotiated increases of 12 percent over the legal costs, while those related to textiles have an average percentage premia of 21 percent during the period. Given all the foregoing, the cost of labor variable was defined as

7. The Wage Survey is carried out on a monthly basis at establishments belonging to all economic sectors. 


$$
\begin{aligned}
\text { Cost of Labor }=\mathrm{CL}= & \text { Wage* }(1+\text { legal nonwage costs } \\
& + \text { bargained nonwage costs }) .
\end{aligned}
$$

\subsubsection{Variable Definitions}

Employment $(N)$ refers to total number of production workers obtained from the Quarterly and Annual Industrial Surveys at the two-digit level. An index of production $(Q)$ is available on a quarterly basis (INE). The index was then transformed to monetary values using the 1988 Industrial Census and the Annual Industrial Survey (INE). Data on product prices ( $p$ ) refer to the producer price index (PPI) at the two-digit level (INE). All data refer to monthly values calculated as an average on a quarterly basis.

\subsubsection{Some Corrections to the Official Data}

In Uruguay, the industrial census is performed every 10 years. Each time a census is done, annual and quarterly surveys update their samples based on the new information. These samples are such that those establishments with more than 50 or 100 workers (depending on their share on the industry value added) are always surveyed (hence, death and births are accounted for), while smaller plants are sampled at the beginning of the period and remain in the sample until the new industrial census is carried out. In 1988, the last national industrial census was performed and its results showed that the samples that were being used in the industrial surveys - stemming from the 1978 census - were severely misrepresenting the different sectors. Annual surveys started including the new information in 1989, while quarterly surveys did so in 1993. However, no correction to the data was done before those dates. The differences in the samples meant that the estimated levels of employment and output for the whole manufacturing sector differed by about 25 percent depending on the sample used. At the two-digit level there were even broader differences. It was thus decided to correct the official data, discussing and taking advice from those in charge of the surveys at the INE. Given that the 1982-1983 economic recession had major and different effects, depending on the industrial sector, the assumption used to calculate the new data was that the lack of representativeness of the 1978 sample went back to 1984 . As other sources showed that the evolution of the variables stemming from the surveys along the post-1984 period was quite correct, the differences in the levels according to both samples were geometrically distributed along those years (1984-1988 for the annual survey; 1984-1993 for the quarterly survey).

\subsubsection{Degree of Openness: OPEN}

The index was calculated as total exports plus total imports divided by value added, per manufacturing industry. Data came from the Republic 
Bank of Uruguay (BROU), which was the authority in charge of collecting the data.

\subsubsection{Alternative Wages: AW}

Alternative wages were calculated using the information of wages in manufacturing as described in 8.4.1 and that of average income of selfemployed individuals according to the Household Survey. The alternative income for a worker in industry $j$ was defined as the weighted average of the wage in the rest of the manufacturing industries; the income the worker would receive if he/she becomes unemployed and collects unemployment benefits (50 percent of his/her current wage); and the average income of self-employed individuals. Weights were defined as the annual frequency of each category as stemming from the Household Survey.

\subsubsection{Union Density: UNION}

Union density was calculated using annual number of production workers as stemming from the Industrial Surveys and total membership reported by the National Union Federation after each congress. Congresses took place in 1985, 1987, 1990, 1993, and 1996-1997. In intervening years, union membership is estimated through simple interpolation.

Descriptive statistics for the above variables are summarized in table 8.2, differentiating between the pre- and postreunionization subperiods (19751984 and 1985-1997). Data for the entire manufacturing sector are reported to indicate overall trends; data for manufacturing industries indicate the diversity of conditions across different markets. Note that with the return of collective bargaining, the market trends are toward greater production, reduced employment, higher wages, and increased openness.

To preview the dynamic patterns of the key variables, the quarterly change in employment for the manufacturing sector is plotted along with the quarterly changes in production and employment (all in logs) in figures 8.4 and 8.5. Employment varied less on a quarterly basis with the return of unionization; the standard deviation of the log change in employment fell from 0.036 in $1975-1984$ to 0.028 in 1985-1997. At the same time production became more variable, with the standard deviation of log change rising from 0.063 to 0.095 for the same two periods. This would indicate a strong likelihood that employment-output elasticity fell after 1985. The story for wages is less clear-cut. The standard deviation of the log change in wages decreased from 0.124 to $0.063{ }^{8}$ Proportionally speaking, the quarterly variation in wages fell by more than the quarterly variation in employment, indicating a possible increase in the wage elasticity of labor de-

8. The null hypothesis of no change in the variance is rejected at the 5 percent level for all three variables and at the 1 percent level for wages and output, with $F(38,51)=3.85$ for $\log$ wages, $F(38,51)=2.27$ for $\log$ output and $F(38,51)=1.65$ for $\log$ employment. 


\begin{tabular}{|c|c|c|c|c|c|c|c|c|}
\hline \multirow[b]{2}{*}{ Variable } & \multicolumn{4}{|c|}{ 1975.1-1984.4 (Obs. $=40)$} & \multicolumn{4}{|c|}{ 1985.1-1997.4 (Obs. = 52) } \\
\hline & Mean & SD & Max. & Min. & Mean & SD & Max. & Min. \\
\hline \multicolumn{9}{|c|}{ Manufacturing Sector } \\
\hline$W$ & 82.02 & 13.97 & 103.6 & 56.81 & 90.02 & 21.64 & 133.3 & 52.38 \\
\hline LNWC & 1.336 & 0.071 & 1.426 & 1.243 & 1.332 & 0.031 & 1.375 & 1.290 \\
\hline BNWC & 1.000 & 0.000 & 1.000 & 1.000 & 1.123 & 0.038 & 1.156 & 1.000 \\
\hline TLC & 109.7 & 18.6 & 143.54 & 72.56 & 136.2 & 36.34 & 203.7 & 67.79 \\
\hline AW & 0.000 & 0.000 & 0.000 & 0.000 & 42.95 & 11.67 & 62.59 & 24.87 \\
\hline UNION & 0.000 & 0.000 & 0.000 & 0.000 & 0.365 & 0.129 & 0.601 & 0.200 \\
\hline OPEN & 0.298 & 0.036 & 0.388 & 0.242 & 0.468 & 0.109 & 0.620 & 0.295 \\
\hline$Q$ & 57.00 & 6.740 & 70.00 & 44.60 & 60.16 & 5.097 & 71.04 & 49.16 \\
\hline$N$ & 108,143 & 14,496 & 129,491 & 86,010 & 104,782 & 19,727 & 129,995 & 71,735 \\
\hline & \multicolumn{4}{|c|}{$1975.1-1984.4($ Obs. $=240)$} & \multicolumn{4}{|c|}{$1985.1-1997.4($ Obs. $=312)$} \\
\hline & Mean & SD & Max. & Min. & Mean & SD & Max. & Min. \\
\hline \multicolumn{9}{|c|}{ Manufacturing Industries } \\
\hline$W$ & 86.93 & 28.84 & 202.9 & 41.90 & 104.8 & 40.96 & 246.3 & 41.25 \\
\hline LNWC & 1.337 & 0.071 & 1.433 & 1.238 & 1.328 & 0.038 & 1.383 & 1.232 \\
\hline BNWC & 1.000 & 0.000 & 1.000 & 1.000 & 1.076 & 0.096 & 1.265 & 1.000 \\
\hline TLC & 115.3 & 35.31 & 255.6 & 58.65 & 151.4 & 68.23 & 405.8 & 53.23 \\
\hline AW & 0.000 & 0.000 & 0.000 & 0.000 & 69.88 & 21.27 & 136.7 & 30.79 \\
\hline UNION & 0.000 & 0.000 & 0.000 & 0.000 & 0.507 & 0.285 & 1.000 & 0.083 \\
\hline OPEN & 0.338 & 0.257 & 1.149 & 0.096 & 0.575 & 0.657 & 3.500 & 0.102 \\
\hline$Q$ & 9.431 & 6.971 & 27.42 & 1.598 & 9.804 & 6.784 & 26.69 & 1.296 \\
\hline$N$ & 17,661 & 12,763 & 49,715 & 4,167 & 16,543 & 12,292 & 42,150 & 3,897 \\
\hline
\end{tabular}

Notes: $W$ is monthly real wage per production worker in 1988 pesos; LNWC is $1+$ percentage increase in wages due to legal nonwage costs; BNWC is $1+$ percentage increase in wages due to bargained nonwage costs; TLC are monthly total real labor costs in 1988 pesos; AW is the monthly real alternative wage in 1988 pesos; UNION is percentage union; OPEN is degree of openness; $Q$ is production in 1988 million pesos; $N$ is number of production workers; Obs. is the number of observations; and SD represents standard deviation.

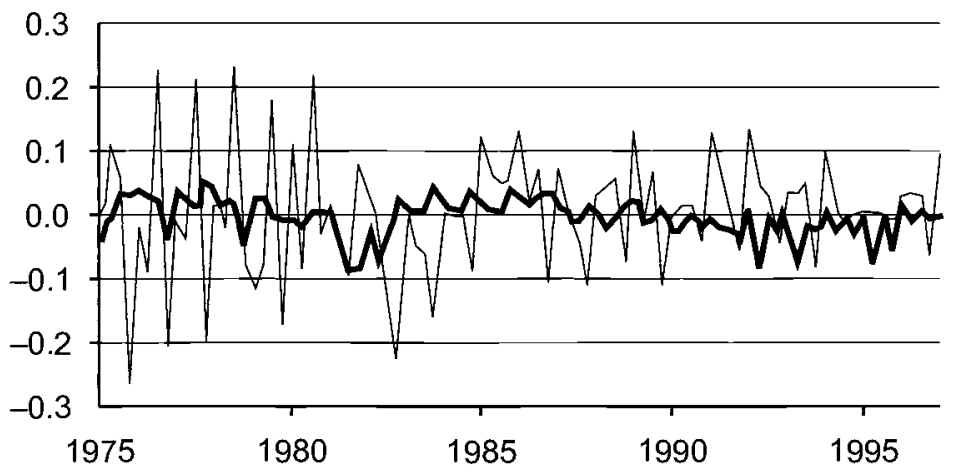

$\mathrm{Dlog} L-\mathrm{Dlog} W$

Fig. 8.4 Log changes in employment and wages 


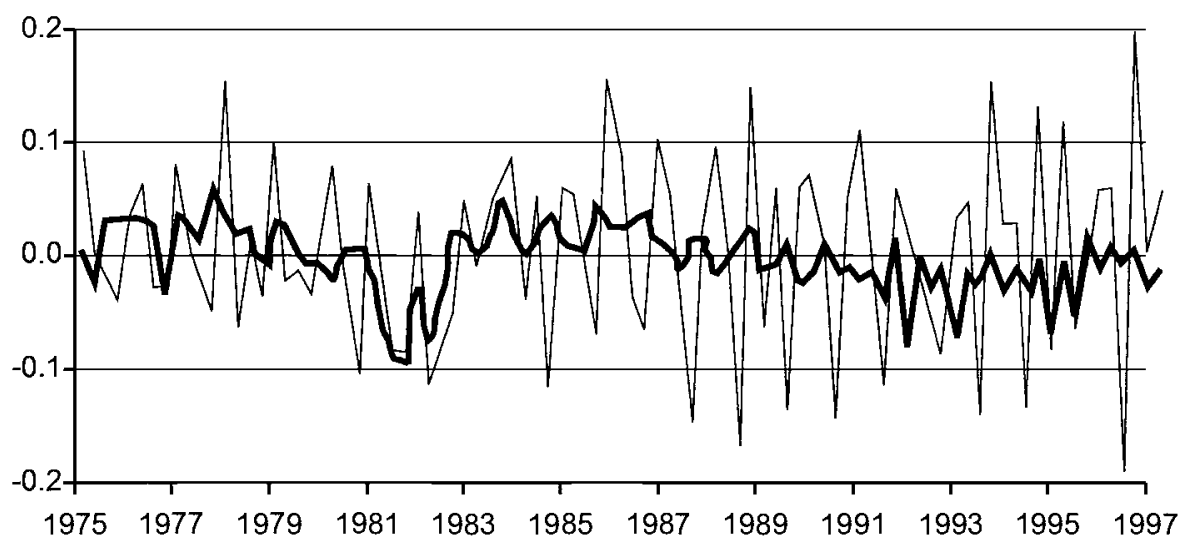

\section{Dlog L - D log Q}

Fig. 8.5 Log changes in employment and production

mand. However, between 1975 and 1980 there are six nearly consecutive episodes of a sharp ( 0.1 or larger) increase in wages followed one or two quarters later by an equally sharp decrease in wages. It is doubtful that employers reacted very much to such short-term wage shocks.

\subsection{Labor Demand: Empirical Results}

\subsubsection{Specifying a Model for the Whole Period}

To determine whether and how much elasticities and adjustment lags of labor demand in the manufacturing sector changed after the return of collective bargaining, we must first establish the appropriate specification of the empirical model. ${ }^{9}$ The quarterly data on the six manufacturing industries described in previous sections was used. To estimate equation (1) as it stands, the stationarity of the variables must first be established, which we did by estimating the order of integration of employment, labor costs, and output for each manufacturing industry in the 1975-1997 period. All variables are nonstationary, but their first differences are stationary so that they are integrated of first order-I(1). The unit root tests used to perform the analyses were those proposed by Fuller (1976), known as Augmented Dickey-Fuller tests (ADF). The models over which the tests were performed were different depending on the variable and industry, including only a constant and lags of the dependent variable in some cases, while in

9. We are grateful to John E. Driffill for his useful comments as well as to Fernando Lorenzo for his econometric advice. 
others they also incorporated seasonals and a time trend (for details, see table 8A.1). These results are somewhat expected. Regarding employment, output, and real wages, accumulated knowledge and productivity shocks have been found to generate stochastic trends in these variables, as was mentioned in section 8.3. The nonstationarity of the degree of openness could be interpreted in similar terms, with external shocks and trade policies at the root of the result. Finally, the most likely explanation for the stochastic trend found in the union density variable should be linked to membership dynamics and insider-outsider arguments (Blanchard and Summers 1986). Given the statistical properties of the data, one possible strategy is to estimate the model in differences.

The institutional framework depicted in previous sections suggests, as a second step, the analysis of the stability of the parameters in time. The model in differences was thus estimated industry by industry, using recursive least squares (RLS) and assuming wages and output are exogenous. The results, depicted in figure 8.6, show there are structural breaks in the labor demand equation in all industries except nonmetallic minerals. The timing of the breaks is not identical in each industry, but breaks can be identified at some point in the early 1980s as well as at another point around 1991-1993. These dates can be clearly related to the major economic crisis in 1982-1984; the end of the military regime in 1985; and the end of government participation in the Wage Councils.

A third stage of the analysis involved using the pooled cross-section time series data set. Given the nonstationarity of the variables and the instability of the parameters, the model was specified in differences with the parameters shifting in various combinations of 1983, 1985, and 1993 and estimated by ordinary least squares (OLS). Elasticities were imposed to be the same for all six industries, while wages and output were taken as exogenous variables. These results are reported in table 8.3.

The first three columns test for a single break in 1983, 1985, and 1993. The null hypothesis of no shifts cannot be rejected for 1983 and 1993, but it is rejected for 1985. The output coefficient falls from 0.141 in 1975-1984 to 0.073 in 1985-1997. The wage coefficient becomes smaller in absolute value terms, going from -0.103 to -0.047 . The sum of the two lagged employment coefficients falls from 0.196 to 0.022 . The models in the last two columns test for multiple break points. Having established a shift in the early 1980s, these results examine whether there was an additional shift in 1993. In the fourth column, breaks in 1983 and 1993 are included, while in the fifth column the shifts take place in 1985 and 1993. The joint null hypothesis of no breaks is rejected in both cases.

Finally, cointegration techniques were also applied. When variables are nonstationary, the estimation of the model in levels has been proven to be misleading, unless the variables are jointly stationary; that is, they are cointegrated. Hence, cointegration (CI) tests were then done to see if an equi- 


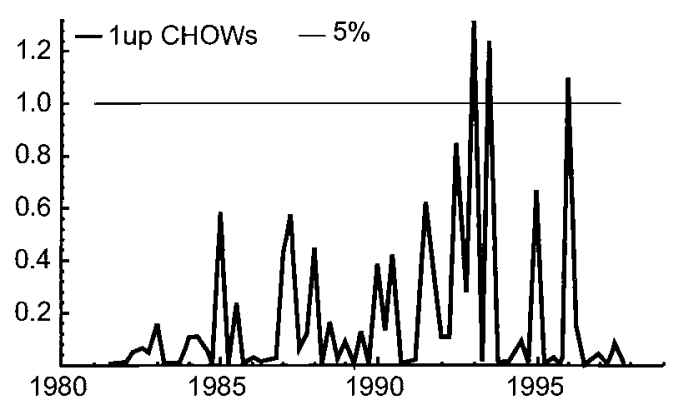

Food, beverage \& tobacco: breaks in 1992-93

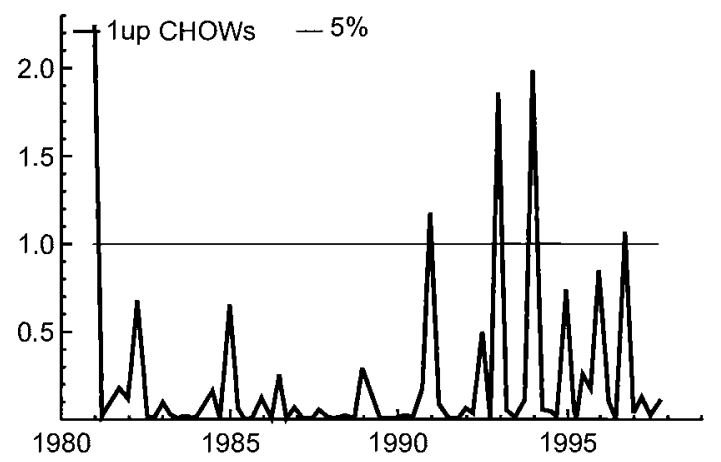

Paper products: breaks in 1991-92

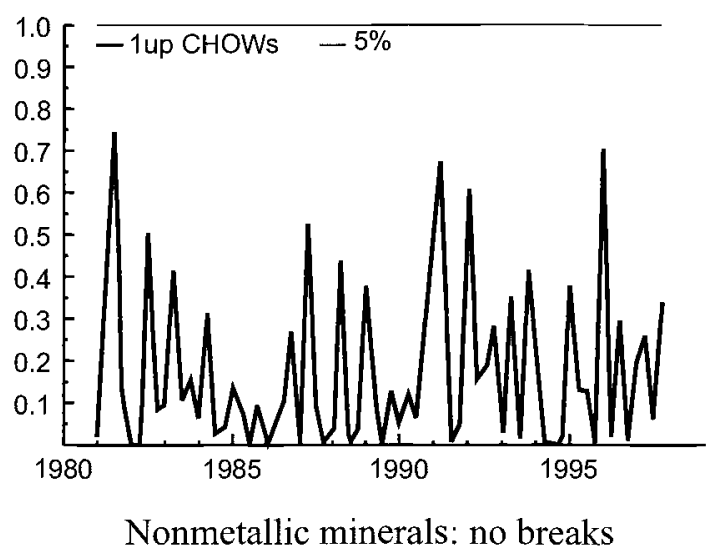

Fig. 8.6 Recursive residuals, by industry 


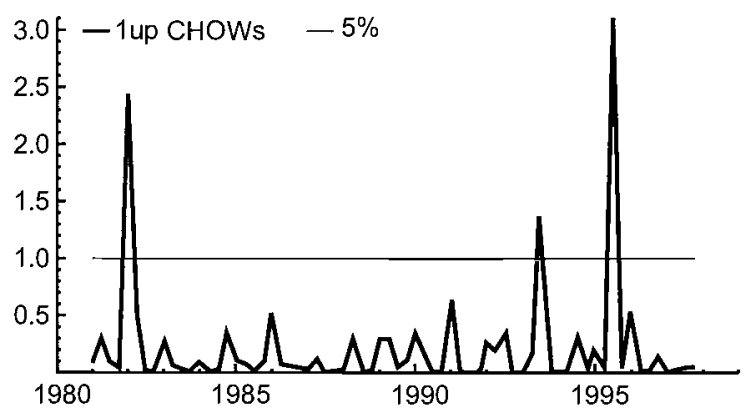

Textiles \& apparel: breaks in 1982-95

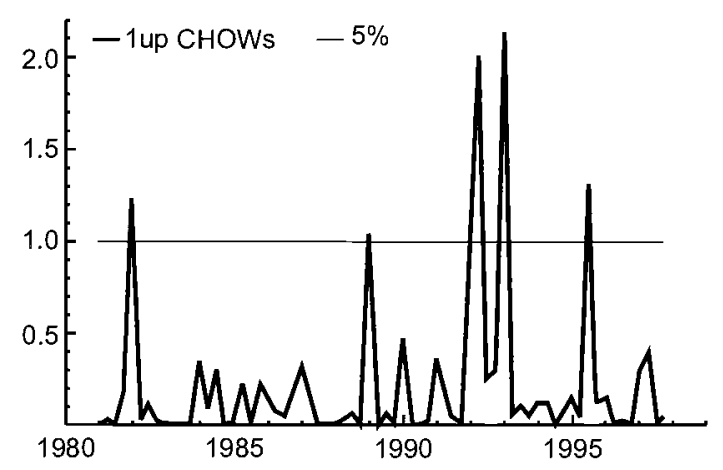

Chemicals: breaks in 1982-93

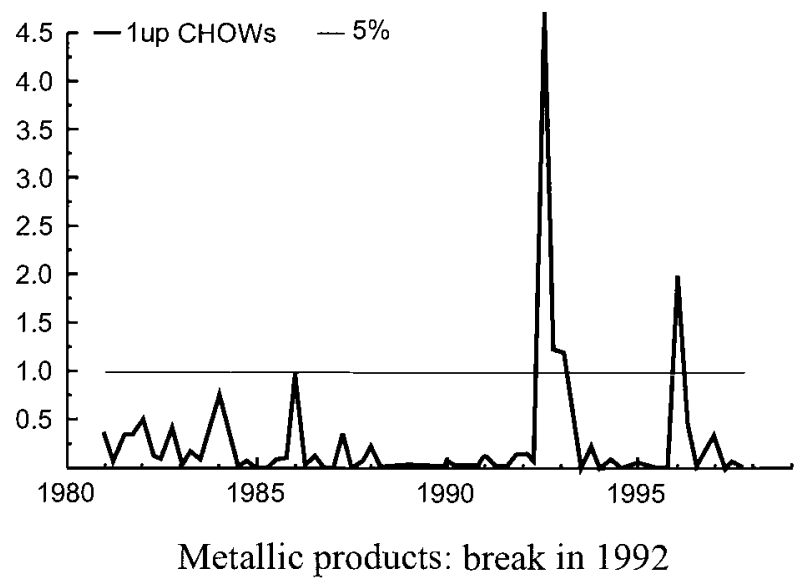

Fig. 8.6 (cont.) 
Estimation in Differences, Manufacturing Industries, 1975-1997

\begin{tabular}{|c|c|c|c|c|c|}
\hline \multirow[b]{2}{*}{ Variable } & \multicolumn{5}{|c|}{ Structural Breaks } \\
\hline & 1983 & 1985 & 1993 & 1983 and 1993 & 1985 and 1993 \\
\hline \multirow[t]{2}{*}{ Employment $_{t-1}$} & 0.01256 & 0.04312 & 0.02399 & 0.01316 & 0.03833 \\
\hline & $(0.0604)$ & $(0.0564)$ & $(0.0468)$ & $(0.0593)$ & $(0.0557)$ \\
\hline \multirow[t]{2}{*}{ Employment $_{t-2}$} & 0.16010 & 0.15278 & 0.09722 & 0.16832 & 0.15082 \\
\hline & $(0.0605)$ & $(0.0564)$ & $(0.0469)$ & $(0.0594)$ & $(0.0559)$ \\
\hline \multirow[t]{2}{*}{ Product $_{t}$} & 0.15244 & 0.14078 & 0.12545 & 0.15180 & 0.14259 \\
\hline & $(0.0306)$ & $(0.0263)$ & $(0.0203)$ & $(0.0300)$ & $(0.0260)$ \\
\hline \multirow[t]{2}{*}{ Wage $_{t}$} & -0.08480 & -0.10309 & -0.09007 & -0.08364 & -0.10675 \\
\hline & $(0.0296)$ & $(0.0234)$ & $(0.0224)$ & $(0.0291)$ & $(0.0264)$ \\
\hline \multirow[t]{2}{*}{ 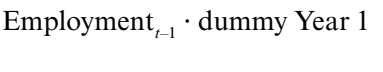 } & -0.01144 & -0.07197 & -0.08663 & 0.01955 & -0.06430 \\
\hline & $(0.0833)$ & $(0.0835)$ & $(0.1043)$ & $(0.0943)$ & $(0.0995)$ \\
\hline \multirow[t]{2}{*}{ Employment $_{t-2} \cdot$ dummy Year 1} & -0.11730 & -0.10185 & 0.03228 & -0.21630 & -0.20982 \\
\hline & $(0.0837)$ & $(0.0839)$ & $(0.1051)$ & $(0.0950)$ & $(0.1002)$ \\
\hline \multirow[t]{2}{*}{ Product $_{t} \cdot$ dummy Year 1} & -0.05929 & -0.0679 & -0.05994 & -0.04599 & -0.04991 \\
\hline & $(0.0374)$ & $(0.0349)$ & $(0.0388)$ & $(0.0410)$ & $(0.0430)$ \\
\hline \multirow[t]{2}{*}{ Wage $_{t} \cdot$ dummy Year 1} & 0.01234 & 0.05570 & 0.09638 & -0.01371 & 0.04344 \\
\hline & $(0.0424)$ & $(0.0244)$ & $(0.0704)$ & $(0.0449)$ & $(0.0507)$ \\
\hline \multirow[t]{2}{*}{ Employment $_{t-1} \cdot$ dummy Year 2} & & & & -0.24582 & -0.18643 \\
\hline & & & & $(0.1233)$ & $(0.1293)$ \\
\hline \multirow[t]{2}{*}{ Employment $_{t-2} \cdot$ dummy Year 2} & & & & 0.03721 & 0.04908 \\
\hline & & & & $(0.1213)$ & $(0.1273)$ \\
\hline \multirow[t]{2}{*}{ Product $_{t} \cdot$ dummy Year 2} & & & & -0.03598 & -0.02352 \\
\hline & & & & $(0.0430)$ & $(0.0473)$ \\
\hline \multirow[t]{2}{*}{ Wage $_{t} \cdot$ dummy Year 2} & & & & 0.13014 & 0.09706 \\
\hline & & & & $(0.0747)$ & $(0.0793)$ \\
\hline$R^{2}$ & 0.0930 & 0.1028 & 0.0922 & 0.1398 & 0.1344 \\
\hline
\end{tabular}

Notes: Dependent variable: $\Delta$ Employment $_{t}=$ Employment $_{t}-$ Employment $_{t-1}$. Variables are in first differences; Employment is number of production workers; Wage is the real labor cost of a production worker; dummy Year 1 is a dummy variable that is equal to 1 in the subperiod starting in 1983, 1985, or 1993 according to the column; dummy Year 2 is a dummy variable that is equal to 1 in the subperiod starting in 1993. Standard errors are in parentheses below each estimated coefficient. No. of observations $=534$.

librium relationship could be sustained for the whole period. Both Engle and Granger (EGM) and Johansen (JM) methods were used, specifying various models that differ in the number of lags included, as well as in the inclusion of seasonal dummies or a constant. Cointegration between employment, production, and labor costs was rejected for all industries according to at least some of the tests performed (table 8A.2). In those cases in which $\mathrm{CI}$ cannot be rejected, the graph of the CI relation shows it is not stationary so that it is probably spurious, as is the existence of a structural break in the relation that makes the statistics significant (see figures 8A.1 to 8A.4).

In summary, all the previous analyses suggest 1985 stands out on both institutional and statistical grounds as the date at which a structural change in labor demand behavior took place. There is also some evidence 
of a further shift in the 1990s. These break points will be used in the remainder of the chapter.

\subsubsection{Specifying a Model for Each Subperiod}

Once we determined 1985 as the breaking point, we first repeated the analysis of order of integration and cointegration of variables for each subsample and each industry. For 1975-1984 and 1985-1997, every variable is I(1) within each subperiod. Details are reported in tables 8A.3 and 8A.4. Second, for 1975-1984, the tests using EGM and/or JM report a CI relation for at least one model (see table 8A.5). ${ }^{10}$ For 1985-1997, no CI among employment, labor costs, and production can be found in any industry for any model using EGM. However, CI is not rejected in any industry once variables that would reflect a bargaining framework - alternative wages, bargained costs, degree of openness, and union density-are included. The existence of an equilibrium relation between the variables - according to the nonrejection of $\mathrm{CI}$-would state that shocks, having a long-lasting effect on each of the individual variables, alter equilibrium only in a transitory way. In the first subperiod, the result is consistent with a standard neoclassical labor demand framework. In 1985-1997, however, the need to include other variables to achieve CI suggests that the framework in which labor demand has been determined actually changed. One possibility is to link the existence of a stochastic trend in the residuals to not having modeled technical change. One might argue that this is partially captured when adding the degree of openness: Increases in openness would force the different industries to invest in new technology once they face greater competitive pressures, or it would force firms with older technologies to close so that, on average, technical progress would be observed. However, as not only openness but variables accounting for bargaining are included in the CI relation, there is also evidence supporting the premise that a bargaining framework is in place to analyze the labor demand schedule in 1985-1997.

To further establish whether the return of collective bargaining was a likely cause of the observed change in parameters, we then performed exogeneity tests on wages. In the competitive model, wages are assumed to be exogenous to the firm and industry, while in the bargaining model, they are not. In the latter case they would be set either simultaneously or subject to the determination of employment. Using a Hausman test (1978) in which the OLS estimate of the wage parameter is compared to a seemingly unrelated regressions estimate (SUR), weak exogeneity of wages cannot be rejected in the first subperiod while it is rejected in the second. ${ }^{11}$ The SUR es-

10. The EGM was preferred due to the number of observations available. The JM was used for paper and chemicals to check if a CI relation could be found.

11. The Hausman statistic is $T(b \mathrm{OLS}-b$ SUR $) 2 \operatorname{Var}(b \mathrm{OLS}-b \mathrm{SUR})-1$, where $b$ is the estimator, by OLS or SUR, and $T$ is the number of observations. It is distributed as a $\chi^{2}$ with 1 degree of freedom. 
Weak Exogeneity Tests for Wages, 1975-1984 and 1985-1997

\begin{tabular}{lcc}
\hline & $1975-1984$ & $1985-1997$ \\
\hline Model 1 & 3.02 & 5.9 \\
Model 2 & - & 90.4 \\
Model 3 & - & 294.2 \\
Model 4 & - & 226.6 \\
Hausman Statistic 95\% confidence & & 3.84 \\
\hline
\end{tabular}

Notes: Each model contains 5 industry dummies and a constant. In models 1 and 2 labor demand is specified as a function of wages and output, using 4 lags of every variable. In models 3 and 4 a dummy variable for 1993 is also included in both the labor demand and the wage equations. In models 1 and 3, instruments used for the wage are just its lags while in models 2 and 4 instruments for the wage include bargaining variables.

timator is calculated using lags of the wage as instruments in both subperiods. For 1985-1997, however, the test was also performed including bargaining variables (degree of openness and union density). Further, given the evidence on the existence of instability in the 1990s, the statistics were also calculated, including a dummy variable in the equations, which takes the value 0 before 1993 and 1 after that date. The values of the statistics for the different models are reported in table 8.4. The results provide further support for estimating a standard neoclassical labor demand model for 1975-1984 and a bargaining model for 1985-1997. Given all the previous results, the estimated models are as follows:

$$
\begin{aligned}
\text { 1975-1984: } \ln N_{t}= & \alpha_{0}+\alpha_{1}(L) \ln \left(\frac{w}{p}\right)_{t}+\alpha_{2}(L) \ln Q_{t}+\alpha_{3}(L) \ln N_{t-1} \\
1985-1997: \ln N_{t}= & \beta_{0}+\beta_{1}(L) \ln \left(\frac{w}{p}\right)_{t}+\beta_{2}(L) \ln Q_{t}+\beta_{3}(L) \ln N_{t-1} \\
\ln \left(\frac{w}{p}\right)_{t}= & \gamma_{0}+\gamma_{1}(L) \mathrm{UNION}+\gamma_{2}(L) \mathrm{OPEN}+\gamma_{3}(L) \ln \left(w_{a}\right)_{t} \\
& +\gamma_{4}(L) \ln \left(\frac{w}{p}\right)_{t-1},
\end{aligned}
$$

where $N$ refers to number of production workers; $w / p$ are real labor costs (which after 1985 include bargained costs); $Q$ is production; union is union density; open is degree of openness; and $w_{a}$ is the alternative wage. The order of the polynomials in the lag operator will be tested empirically, starting with polynomials of order four. The bargaining model is a recursive, two-equation model, so gains in efficiency can be achieved through simultaneous estimation. To avoid possible endogeneity bias due to the nonmodeling of output, lag values of $Q$ (up to two lags), seasonals, and industry dummies were used as instruments for this variable in the estimation for both subperiods. Hence, estimation was done using instrumental variables 
(IVE) in the first subsample and three-stage least squares (3SLS) in the second, using PCGive and PCFiml 9.0 software (1996). The data set is the pooled cross-section time series described previously. Fixed effects per industry are always allowed for. Elasticities are imposed to be equal for all industries so that the estimates reflect the average elasticities for the whole manufacturing sector.

\subsubsection{Main Results}

For both subperiods, table 8.5 reports three simple versions of the labor demand model. Starting with a model including up to four lags for every variable, sequential reductions were performed. Further, the different coefficients were allowed to vary in 1993 in order to check for possible shifts. We only report the last two steps including the shifts that were significant as well as two lags of employment in column (1) and only previous-quarter employment in column (2). Column (3) includes the variable OPEN in the labor demand equation, so as to test if increased openness was affecting the estimates. The wage equation for the bargaining model allows the wage bargain to vary by industry after 1993. This was done to test whether the change in the bargaining structure has had an overall impact on wage demands and whether the effect varies by industry. Residuals are not autocorrelated, but they are heteroskedastic. Thus, standard errors were calculated according to White (1980). Although normality is rejected, hypothesis testing results should be robust to nonnormality given the sample size (Spanos 1986).

As can be seen by comparing columns (1) and (2) of the labor demand results within each subperiod, employment from one quarter ago has an effect on employment in the current quarter, but employment from two quarters ago has no impact. Further, the degree of openness is not only statistically nonsignificant, but does not alter the estimates of the relevant elasticities. Accordingly, our attention will focus on the results for column (2). These show three major results:

1. The output coefficient falls from 0.093 in $1975-1984$ to 0.040 in $1985-$ 1997.

2. The wage coefficient falls (in absolute value) from -0.102 in 1975 1984 to -0.039 in $1985-1997$.

3. There is no significant change in the impact of lagged employment between these two periods.

The wage equation results show that the effect of union density on wages decreased significantly after 1992, although the extent of this change varies per industry. ${ }^{12} \mathrm{~A}$ key finding in the wage equation results is that bargained

12. The negative effect of unions on wages should be taken just as an indicator of changes in the bargaining regime by the mid-1990s. The available number of temporal observations is not enough to estimate different models for the subperiods, so structural breaks in this case are used to capture possible shifts and not as a quantitative assessment. 


\begin{tabular}{|c|c|c|c|c|c|c|}
\hline \multirow[b]{2}{*}{ Variable } & \multicolumn{3}{|c|}{ Sample: 1975-1984 } & \multicolumn{3}{|c|}{ Sample: 1985-1997 } \\
\hline & (1) & (2) & (3) & (1) & (2) & (3) \\
\hline \multicolumn{7}{|c|}{ Labor Demand Equation: dependent variable: $N_{t}$} \\
\hline Constant & $\begin{array}{c}1.4969 \\
(0.2980)\end{array}$ & $\begin{array}{c}1.3840 \\
(0.3012)\end{array}$ & $\begin{array}{c}1.5638 \\
(0.3338)\end{array}$ & $\begin{array}{c}1.3403 \\
(0.2333)\end{array}$ & $\begin{array}{c}1.3630 \\
(0.2187)\end{array}$ & $\begin{array}{c}1.3526 \\
(0.2186)\end{array}$ \\
\hline$N_{t-1}$ & $\begin{array}{c}0.90382 \\
(0.1299)\end{array}$ & $\begin{array}{c}0.88844 \\
(0.0315)\end{array}$ & $\begin{array}{c}0.87473 \\
(0.0330)\end{array}$ & $\begin{array}{c}0.79468 \\
(0.0625)\end{array}$ & $\begin{array}{c}0.86921 \\
(0.0218)\end{array}$ & $\begin{array}{r}0.87186 \\
(0.0202)\end{array}$ \\
\hline$N_{t-2}$ & $\begin{array}{c}-0.01477 \\
(0.1181)\end{array}$ & & & $\begin{array}{c}0.07809 \\
(0.0588)\end{array}$ & & \\
\hline$Q_{t}$ & $\begin{array}{c}0.09074 \\
(0.0261)\end{array}$ & $\begin{array}{c}0.0930 \\
(0.0244)\end{array}$ & $\begin{array}{c}0.09092 \\
(0.0239)\end{array}$ & $\begin{array}{c}0.03912 \\
(0.0244)\end{array}$ & $\begin{array}{c}0.04024 \\
(0.0245)\end{array}$ & $\begin{array}{r}0.03309 \\
(0.0173)\end{array}$ \\
\hline$W_{t}$ & $\begin{array}{c}-0.10000 \\
(0.0227)\end{array}$ & $\begin{array}{c}-0.10180 \\
(0.0182)\end{array}$ & $\begin{array}{c}-0.09865 \\
(0.0174)\end{array}$ & $\begin{array}{c}-0.04098 \\
(0.0178)\end{array}$ & $\begin{array}{c}-0.03886 \\
(0.0184)\end{array}$ & $\begin{array}{c}-0.03882 \\
(0.0172)\end{array}$ \\
\hline DUMMY93 & & & & $\begin{array}{c}-0.03957 \\
(0.0123)\end{array}$ & $\begin{array}{c}-0.04019 \\
(0.0126)\end{array}$ & $\begin{array}{c}-0.0393 \\
(0.0122)\end{array}$ \\
\hline IND.31 & $\begin{array}{c}-0.04217 \\
(0.0285)\end{array}$ & $\begin{array}{c}-0.04499 \\
(0.0271)\end{array}$ & $\begin{array}{c}-0.07533 \\
(0.0357)\end{array}$ & $\begin{array}{c}0.08076 \\
(0.0287)\end{array}$ & $\begin{array}{c}0.08336 \\
(0.0287)\end{array}$ & $\begin{array}{r}0.08755 \\
(0.0250)\end{array}$ \\
\hline IND.32 & $\begin{array}{r}0.03857 \\
(0.0247)\end{array}$ & $\begin{array}{r}0.03757 \\
(0.0267)\end{array}$ & $\begin{array}{c}0.02439 \\
(0.0296)\end{array}$ & $\begin{array}{c}0.08019 \\
(0.0206)\end{array}$ & $\begin{array}{c}0.08335 \\
(0.0206)\end{array}$ & $\begin{array}{r}0.08357 \\
(0.0202)\end{array}$ \\
\hline IND.34 & $\begin{array}{c}0.02271 \\
(0.0276)\end{array}$ & $\begin{array}{c}0.02498 \\
(0.0273)\end{array}$ & $\begin{array}{c}-0.03521 \\
(0.0442)\end{array}$ & $\begin{array}{c}-0.05909 \\
(0.0209)\end{array}$ & $\begin{array}{c}-0.06096 \\
(0.0214)\end{array}$ & $\begin{array}{c}-0.06533 \\
(0.0238)\end{array}$ \\
\hline IND.35 & $\begin{array}{c}-0.10358 \\
(0.0242)\end{array}$ & $\begin{array}{c}-0.10557 \\
(0.0221)\end{array}$ & $\begin{array}{c}-0.15528 \\
(0.0409)\end{array}$ & $\begin{array}{c}-0.04310 \\
(0.0246)\end{array}$ & $\begin{array}{c}-0.04563 \\
(0.0249)\end{array}$ & $\begin{array}{c}-0.04006 \\
(0.0201)\end{array}$ \\
\hline IND.36 & $\begin{array}{c}-0.04382 \\
(0.0243)\end{array}$ & $\begin{array}{c}-0.04285 \\
(0.0233)\end{array}$ & $\begin{array}{c}-0.10538 \\
(0.0460)\end{array}$ & $\begin{array}{c}-0.07504 \\
(0.0279)\end{array}$ & $\begin{array}{c}-0.07684 \\
(0.0283)\end{array}$ & $\begin{array}{c}-0.08307 \\
(0.0279)\end{array}$ \\
\hline Qr.1 & $\begin{array}{c}-0.01536 \\
(0.0127)\end{array}$ & $\begin{array}{c}-0.01524 \\
(0.0127)\end{array}$ & $\begin{array}{c}-0.01451 \\
(0.0127)\end{array}$ & $\begin{array}{c}0.00098 \\
(0.0081)\end{array}$ & $\begin{array}{c}-0.00019 \\
(0.0080)\end{array}$ & $\begin{array}{c}-0.00111 \\
(0.0080)\end{array}$ \\
\hline Qr.2 & $\begin{array}{c}0.00815 \\
(0.0079)\end{array}$ & $\begin{array}{c}0.00783 \\
(0.0082)\end{array}$ & $\begin{array}{c}0.00846 \\
(0.0082)\end{array}$ & $\begin{array}{c}0.01122 \\
(0.0059)\end{array}$ & $\begin{array}{c}0.01031 \\
(0.0058)\end{array}$ & $\begin{array}{c}0.00996 \\
(0.0053)\end{array}$ \\
\hline Qr.3 & $\begin{array}{c}-0.01340 \\
(0.0069)\end{array}$ & $\begin{array}{c}-0.01323 \\
(0.0067)\end{array}$ & $\begin{array}{c}-0.01286 \\
(0.0068)\end{array}$ & $\begin{array}{c}-0.01589 \\
(0.0072)\end{array}$ & $\begin{array}{c}-0.01778 \\
(0.0069)\end{array}$ & $\begin{array}{c}-0.01793 \\
(0.0067)\end{array}$ \\
\hline OPEN & & & $\begin{array}{c}-0.07185 \\
(0.0532)\end{array}$ & & & $\begin{array}{r}-0.00090 \\
(0.0092)\end{array}$ \\
\hline No. of observations & 228 & 228 & 228 & 300 & 300 & 300 \\
\hline$R^{2}$ & 0.9946 & 0.9947 & 0.9947 & 0.9967 & 0.9967 & 0.9967 \\
\hline AR $1-4$ & $\begin{array}{c}3.3058 \\
{[0.5080]}\end{array}$ & $\begin{array}{c}3.5757 \\
{[0.4665]}\end{array}$ & $\begin{array}{c}3.9374 \\
{[0.4145]}\end{array}$ & $\begin{array}{c}1.2294 \\
{[0.8732]}\end{array}$ & $\begin{array}{c}1.7403 \\
{[0.7834]}\end{array}$ & $\begin{array}{c}1.7430 \\
{[0.7829]}\end{array}$ \\
\hline Normality & $\begin{array}{c}143.0 \\
{[0.0000]^{* *}}\end{array}$ & $\begin{array}{c}138.0 \\
{[0.0000]^{* *}}\end{array}$ & $\begin{array}{c}131.7 \\
{[0.0000]^{* *}}\end{array}$ & $\begin{array}{c}60.4 \\
{[0.0000]^{* *}}\end{array}$ & $\begin{array}{c}56.6 \\
{[0.0000]^{* *}}\end{array}$ & $\begin{array}{c}56.7 \\
{[0.0000]^{* *}}\end{array}$ \\
\hline$\chi^{2}$ & $\begin{array}{c}2.9151 \\
{[0.0002]^{* *}}\end{array}$ & $\begin{array}{c}2.272 \\
{[0.0067]^{* *}}\end{array}$ & $\begin{array}{c}2.309 \\
{[0.0039]^{* *}}\end{array}$ & $\begin{array}{c}1.5052 \\
{[0.0353]^{*}}\end{array}$ & $\begin{array}{c}1.7656 \\
{[0.0074]^{* *}}\end{array}$ & $\begin{array}{c}1.5585 \\
{[0.0247]^{* *}}\end{array}$ \\
\hline & $\mathrm{Sa}$ & nple: 1985 & & & & \\
\hline & $(1$ & (2) & (3) & & & \\
\hline
\end{tabular}

Wage Equation: dependent variable: $W_{t}$

$\begin{array}{lccc}\text { Constant } & -0.29674 & -0.27408 & -0.27471 \\ & (0.1068) & (0.1041) & (0.1041) \\ W_{t-1} & 0.36874 & 0.43003 & 0.43033 \\ & (0.0563) & (0.0401) & (0.0402)\end{array}$

(continued) 


\begin{tabular}{|c|c|c|c|}
\hline & \multicolumn{3}{|c|}{ Sample: 1985-1997 } \\
\hline & (1) & (2) & (3) \\
\hline$W_{t-2}$ & $\begin{array}{c}0.07493 \\
(0.0433)\end{array}$ & & \\
\hline $\mathrm{AW}_{t}$ & $\begin{array}{c}0.71198 \\
(0.0523)\end{array}$ & $\begin{array}{r}0.72145 \\
(0.0540)\end{array}$ & $\begin{array}{c}0.72126 \\
(0.0540)\end{array}$ \\
\hline $\mathrm{OPEN}_{t}$ & $\begin{array}{c}-0.02471 \\
(0.0107)\end{array}$ & $\begin{array}{c}-0.02426 \\
(0.0107)\end{array}$ & $\begin{array}{c}-0.02424 \\
(0.0107)\end{array}$ \\
\hline $\mathrm{UNION}_{t}$ & $\begin{array}{r}0.15515 \\
(0.0227)\end{array}$ & $\begin{array}{r}0.15477 \\
(0.0229)\end{array}$ & $\begin{array}{r}0.15470 \\
(0.0229)\end{array}$ \\
\hline $\mathrm{UNION} 3_{t}$ & $\begin{array}{c}-0.23953 \\
(0.0693)\end{array}$ & $\begin{array}{c}-0.23432 \\
(0.0703)\end{array}$ & $\begin{array}{r}-0.23437 \\
(0.0703)\end{array}$ \\
\hline UNION93 $t_{t} \cdot$ Ind. 31 & $\begin{array}{l}0.05711 \\
(0.0846)\end{array}$ & $\begin{array}{c}0.06146 \\
(0.0862)\end{array}$ & $\begin{array}{r}0.06161 \\
(0.0862)\end{array}$ \\
\hline UNION93 ${ }_{t} \cdot$ Ind. 32 & $\begin{array}{c}-0.14993 \\
(0.0784)\end{array}$ & $\begin{array}{r}-0.14841 \\
(0.0809)\end{array}$ & $\begin{array}{c}-0.14815 \\
(0.0809)\end{array}$ \\
\hline UNION93 $\cdot$ Ind.34 & $\begin{array}{c}-0.04242 \\
(0.0745)\end{array}$ & $\begin{array}{c}-0.03842 \\
(0.0763)\end{array}$ & $\begin{array}{c}-0.03838 \\
(0.0762)\end{array}$ \\
\hline UNION93 ${ }_{t} \cdot$ Ind. 35 & $\begin{array}{l}0.17082 \\
(0.0616)\end{array}$ & $\begin{array}{c}0.17512 \\
(0.0627)\end{array}$ & $\begin{array}{c}0.17504 \\
(0.0626)\end{array}$ \\
\hline UNION93 $\cdot$ Ind.36 & $\begin{array}{c}-0.89888 \\
(0.2909)\end{array}$ & $\begin{array}{c}-0.89890 \\
(0.2934)\end{array}$ & $\begin{array}{r}-0.89809 \\
(0.2935)\end{array}$ \\
\hline DUMMY93 & $\begin{array}{r}0.10029 \\
(0.0332)\end{array}$ & $\begin{array}{c}0.10001 \\
(0.0331)\end{array}$ & $\begin{array}{r}0.09997 \\
(0.0331)\end{array}$ \\
\hline Qr.1 & $\begin{array}{c}-0.04555 \\
(0.0107)\end{array}$ & $\begin{array}{c}-0.04357 \\
(0.0109)\end{array}$ & $\begin{array}{c}-0.04358 \\
(0.0109)\end{array}$ \\
\hline Qr.2 & $\begin{array}{c}0.01220 \\
(0.0091)\end{array}$ & $\begin{array}{l}0.02054 \\
(0.0086)\end{array}$ & $\begin{array}{c}0.02056 \\
(0.0086)\end{array}$ \\
\hline Qr.3 & $\begin{array}{r}0.01208 \\
(0.0085)\end{array}$ & $\begin{array}{c}0.00984 \\
(0.0083)\end{array}$ & $\begin{array}{r}0.00985 \\
(0.0083)\end{array}$ \\
\hline No. of observations & 300 & 300 & 300 \\
\hline$R^{2}$ & 0.9780 & 0.9782 & 0.9782 \\
\hline AR 1-4 & $\begin{array}{c}1.9425 \\
{[0.7530]}\end{array}$ & $\begin{array}{c}1.6430 \\
{[0.7928]}\end{array}$ & $\begin{array}{c}1.6429 \\
{[0.7927]}\end{array}$ \\
\hline Normality & $\begin{array}{c}7.74 \\
{[0.0209]^{*}}\end{array}$ & $\begin{array}{c}7.85 \\
{[0.0198]^{*}}\end{array}$ & $\begin{array}{c}7.85 \\
{[0.0198]^{* *}}\end{array}$ \\
\hline$\chi^{2}$ & $\begin{array}{c}1.9445 \\
{[0.0014]^{* *}}\end{array}$ & $\begin{array}{c}2.0968 \\
{[0.0006]^{* *}}\end{array}$ & $\begin{array}{c}1.9892 \\
{[0.0010]^{* *}}\end{array}$ \\
\hline
\end{tabular}

Notes: $N$ is number of production workers; $W$ is the real labor cost of a production worker; $Q$ is production; AW is the alternative wage; UNION is union density; OPEN is the degree of openness; Qr. $j$ is a dummy variable for quarter $j$; Ind. $i$ is a dummy variable for industry $i$; DUMMY93 is a dummy variable equal to 1 in 1993-1997; UNION93 is UNION multiplied by DUMMY93. Industries reported are: food, beverage, and tobacco (31); textiles and apparel (32); paper (34); chemicals (36); nonmetallic minerals (36); metal products (38). Models (1) and (2) differ in that the former includes 2 lags of the dependent variable, while the latter only includes 1 . Model 3 includes the variable OPEN in the labor demand equation. Variables are in logs, except for UNION; OPEN and binary variables. Corrected (according to White, 1980) standard errors are in parentheses below each estimated coefficient. AR 1-4 is a test of autocorrelation of order 4 in the residuals; Normality is Jarque-Bera's test; $\chi^{2}$ is a test for heteroskedasticity of the residuals, using all variables and their squared value in the model for the variance. 


\begin{tabular}{|c|c|c|c|c|}
\hline \multirow[b]{2}{*}{ Variable } & \multicolumn{2}{|c|}{$1975-1984$} & \multicolumn{2}{|c|}{ 1985-1997 } \\
\hline & Estimate & Confidence Interval & Estimate & Confidence Interval \\
\hline \multicolumn{5}{|c|}{ Short Run Estimates } \\
\hline Production & 0.09304 & $(0.045,0.141)$ & 0.040243 & $(0.007,0.087)$ \\
\hline Labor costs & -0.10180 & $(-0.137,-0.066)$ & -0.03886 & $(-0.075,-0.003)$ \\
\hline Lagged employment & 0.88844 & $(0.827,0.950)$ & 0.86921 & $(0.826,0.912)$ \\
\hline \multicolumn{5}{|c|}{ Long Run Estimates } \\
\hline Production & 0.8339 & $(0.525,1.143)$ & 0.3077 & $(0.080,0.536)$ \\
\hline Labor costs & -0.9125 & $(-1.368,-0.457)$ & -0.2971 & $(-0.534,-0.060)$ \\
\hline Labor share $\left(\mathrm{s}_{\mathrm{L}}\right)$ & \multicolumn{2}{|c|}{0.248} & \multicolumn{2}{|c|}{0.257} \\
\hline \multicolumn{5}{|l|}{ Wage elasticity of } \\
\hline labor demand & \multicolumn{2}{|c|}{0.69} & \multicolumn{2}{|c|}{0.22} \\
\hline
\end{tabular}

Notes: $\mathrm{s}_{\mathrm{L}}$ is equal to the wage bill (all wage and nonwage costs included) divided by value added. The wage elasticity of labor demand is equal to $-\left(1-s_{L}\right) \cdot \sigma$, where $\sigma$ is the elasticity of substitution between capital and labor and is given by the estimated coefficient of the wage in the labor demand equation.

wages fall with increased openness. The effect is rather small, however-a 50 point change in openness being associated with a 1.5 percent change in the bargained wage.

Because of the different approaches taken to estimating the IVE labor demand and the 3SLS bargaining model, one might wonder if these findings are sensitive to the choice of estimation method or to the inclusion/exclusion of variables in the model. To put the two subperiods on an equal footing, both models were nested in a two-equation system and estimated by 3SLS. In order to do so, each variable was multiplied by two binary variables - one for 1975-1984, another for 1985-97—so that $X 75$ equals $X$ in $1975-1984$ and 0 after that date, and $X 85$ is equal to $X$ in $1985-1997$ and 0 before that date. Tests of significance of coefficients and tests of coefficients being equal before and after 1985 were performed, and they all reinforce the previous results (see table 8A.5).

In tables 8.6 and 8.7, labor demand elasticities and results for other relevant parameters are summarized, using models (2) of the previous table. Confidence intervals are also reported. These results show that the wage elasticity of labor demand dropped from 0.69 in 1975-1984 to 0.22 in 1985-1997. The employment-output elasticity fell by more than 50 percent, from 0.83 to 0.31 .

The estimated speed of adjustment is the same in both periods, about five quarters, so that there is no evidence that the return of bargaining lengthened the amount of time needed for employment to adjust, which is contrary to what one might generally expect. ${ }^{13}$

13. An exception is the paper by Lockwood and Manning (1989) in which the opposite result is found. 
Table 8.7

Impact of Key Variables on Real Labor Costs: Manufacturing Industries, 1985-1997

\begin{tabular}{|c|c|c|c|c|}
\hline \multirow[b]{2}{*}{ Variable } & \multicolumn{2}{|c|}{ Short Run } & \multicolumn{2}{|c|}{ Long Run } \\
\hline & Estimate & Confidence Interval & Estimate & Confidence Interval \\
\hline Openness & -0.02426 & $(-0.045,-0.003)$ & -0.04256 & $(-0.075,-0.010)$ \\
\hline Alternative wage & 0.72145 & $(0.616,0.827)$ & 1.26580 & $(1.175,1.356)$ \\
\hline Lagged wage & 0.43003 & $(0.351,0.509)$ & & \\
\hline Union 1985/92 & 0.15477 & $(0.110,0.200)$ & 0.27154 & $(0.215,0.328)$ \\
\hline \multicolumn{5}{|l|}{ Union 1993/97 } \\
\hline Ind.31 & -0.01809 & $(-0.176,0.140)$ & -0.03174 & $(-0.328,0.265)$ \\
\hline Ind.32 & -0.22796 & $(-0.384,-0.072)$ & -0.39995 & $(-0.722,-0.078)$ \\
\hline Ind.34 & -0.11797 & $(-0.246,0.010)$ & -0.20698 & $(-0.451,0.037)$ \\
\hline Ind.35 & 0.09557 & $(0.031,0.159)$ & 0.16767 & $(0.062,0.273)$ \\
\hline Ind.36 & -0.97846 & $(-1.585,-0.372)$ & -1.71670 & $(-2.756,-0.677)$ \\
\hline Ind.38 & -0.07955 & $(-0.215,0.056)$ & -0.13957 & $(-0.387,0.108)$ \\
\hline
\end{tabular}

Note: Industries are food, beverage, and tobacco (31); textiles and apparel (32); paper (34); chemicals (36); nonmetallic minerals (36); metal products (38).

Although the estimates might be biased downward due to the omission of hiring and firing costs, the evidence of a decline between both subperiods is quite robust. The smaller responses of employment to changes in output and wages are consistent with collective bargaining restricting the options available to employers. Once unions reappeared and started playing a role in wage setting, the rules of the game changed. Costs of hiring and firing workers were expected to increase because of union resistance. Employment would not adjust to changing output demand as before because of increased uncertainty on the reaction of unions. Hence, there would have been more labor hoarding during slowdowns and increased use of overtime work during upswings than when unions were not active.

After 1992 the structure of bargaining changed, so that firm-level negotiations became quite common in some industries. The effect of this institutional change is captured in both the labor demand and the wage equations, but in different ways. In 1993 the labor demand equation has shifted in, while the other estimated coefficients are stable. Regarding the wage, the estimated effect is an overall increase in wages but with a reduction of the impact of union power on the markup that is different per industry. Industries that have experienced a greater reduction of this positive effect are those in which firm-level negotiations have become more common. Hence, while no significant change is detected in chemicals (35) - a concentrated industry in which public firms are present - in nonmetallic minerals (36), union power has become less effective in increasing the markup over alternative income. The estimated long-run effect of unions is to increase wages by 1.5 percent per each 10 percent increase in coverage in 1985-1992. Given the changes that took place in the 1990s, the average effect is almost 


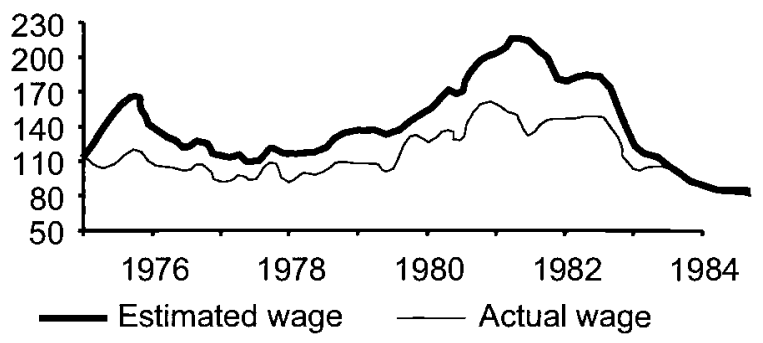

Fig. 8.7 Labor costs 1975-1984 assuming the existence of unions

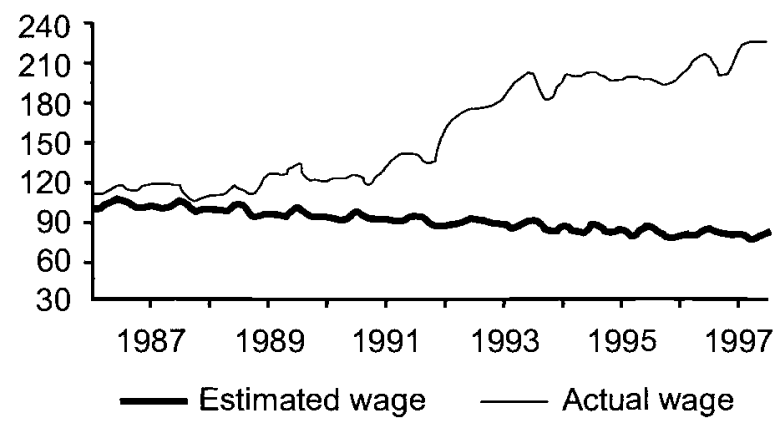

Fig. 8.8 Labor costs 1986-1997 assuming there were no unions

null for the whole period. ${ }^{14}$ The indirect effect of unions over employment via wages is such that an increase in coverage of 10 percentage points is associated with a 0.8 percent decline in labor demand before 1993 .

As almost every parameter changed, a simulation was done using both models in order to capture all possible effects. First, the wage was calculated for the period 1985-1997 using an $\operatorname{ARIMA}(4,1,0)$ model estimated using data for 1975-1984. Comparing the average value of the estimated wage with the actual average value, the result is that wages were 46 percent higher than what they would have been had no changes occurred. For 1975-1984, the same exercise shows that actual wages in the period were 18 percent lower than what they would have been if there had been bargaining over wages and a union density equal to its average value in 1985-1997 (see figures 8.7 and 8.8).

Second, using actual wages and the two specifications of the labor demand equation, the estimated effect of the different regimes on labor demand is that the employment level in 1985-1997 was 9 percent higher than what it would have been according to the 1975-1984 model. This is the combined effect of the decrease in the output and wage parameters. Ac-

14. These effects are calculated at the mean value of UNION. 


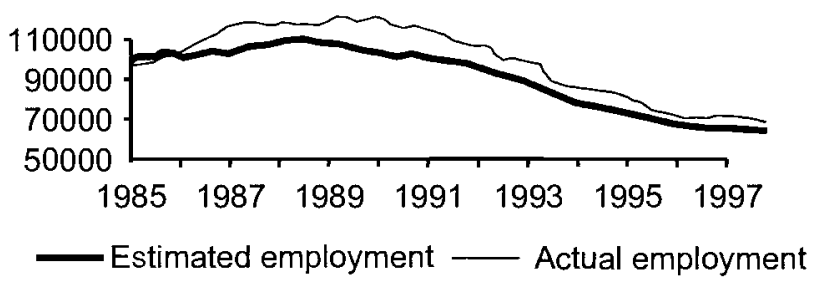

Fig. 8.9 Employment 1986-1997 assuming there were no unions but using actual wages

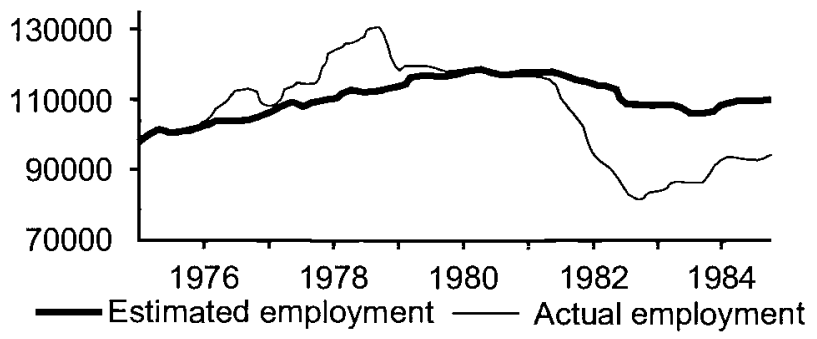

Fig. 8.10 Employment 1975-1984 assuming the existence of unions but using actual wages

cordingly, in 1975-1984, employment would have been 5 percent higher than its observed level if elasticities had been those stemming from the bargaining model (see figures 8.9 and 8.10).

Finally, considering both the estimated wage level and the change in elasticities, the employment level in 1985-1997 was 24 percent lower than what it would have been if wages had followed the 1975-1984 ARIMA(4,1,0) model and elasticities had been those according to the 1975-1984 labor demand equation. In 1975-1984, on the contrary, if wages had been those predicted by the bargaining model and elasticities had had the values estimated with this same model, then the employment level would have been 1 percent lower than what it actually was (see figures 8.11 and 8.12). In summary, unions could have prevented wages from falling as much as they did before 1985 at the cost of a 1 percent employment loss while, if unions had not been reinstated, employment would have been 24 percent higher, but at the cost of a much lower level of earnings.

These figures should be considered only as rough indicators. The ARIMA(4,1,0) model for wages, as well as the 1975-1984 model for employment, do not take into account the 1993 estimated shifts and the role that variables such as output and terms of trade would have played after 1985 in the absence of a regime change. These might be linked to structural reforms and productivity gains brought about by increased openness. Hence, the simulated paths in 1985-1997 are overestimated in the former 


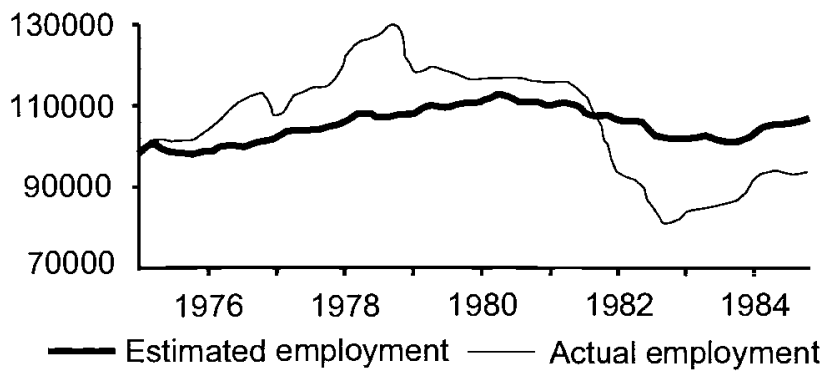

Fig. 8.11 Employment 1975-1984 assuming the existence of unions

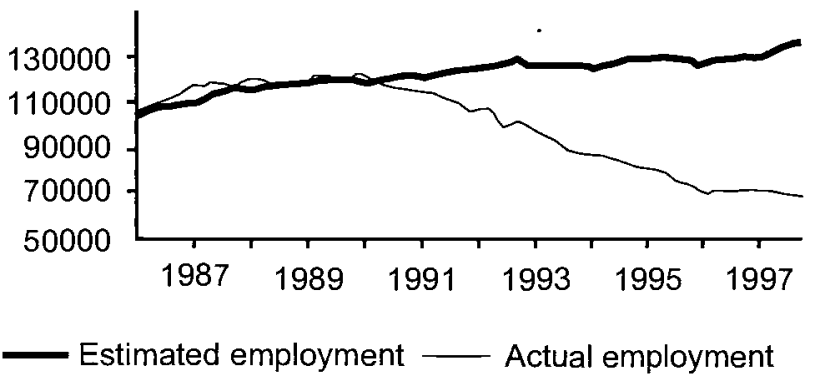

Fig. 8.12 Employment 1986-1997 assuming there were no unions

case, while they are underestimated in the latter using the 1975-1984 models (simulated wage gains and employment losses are smaller than simulated).

All the results discussed above stem from a model for the whole manufacturing sector using industry data in which output and wage elasticities of labor demand were assumed to be the same for all industries. A natural question is if this last assumption holds and, if not, if it is biasing the results significantly. To address the issue, all the coefficients were allowed to vary per industry in both subperiods and the restriction imposed was tested. In 1975-1984, the hypothesis of common elasticities and speed of adjustment was not rejected. For 1985-1997 the wage elasticity and the lagged employment coefficient were statistically equal among industries, while a unique output elasticity was rejected. Paper and chemicals have a significantly smaller elasticity. However, the average elasticity for the manufacturing sector estimated using this model is only slightly higher, while the wage elasticity and the parameter accounting for the speed of adjustment do not show important biases. ${ }^{15}$

Although such similarity between industries is not expected to hold a priori, the statistical result supports the estimation procedure followed us-

15. Results are available upon request. 
ing the pooled cross-section time series data set. Further, the decline in the elasticities holds, no matter how much the amount in which they decreased might be overstated.

Even though no direct bargaining over employment has been observed, all our findings suggest that unions have had an effect on labor demand. This has taken place through two mechanisms. First, reunionization changed the way wages were set. Bargaining over wage levels has been done, taking into account the likely effects on the labor demand schedule and outside opportunities for those that would eventually be unemployed. Industries that have been most exposed to competition have registered lower markups than the rest. Union membership, which has declined systematically all along the period, raised the markup during the 1980s. At the beginning of the 1990s, and probably as a consequence of the progressive decentralization of bargaining and nonenforcement of contracts, this effect has vanished in some industries, while in others it has even become negative. Increased openness also has tempered wage demands by unions.

Second, unions have effectively altered the labor demand choice set for employers. Output and wage elasticities have gone down, and union resistance is one of the probable causes. As unions forced wages up and more limits were posed to pass that increase onto prices, firms have been forced to adjust employment to cyclical variations of demand less than before. Further, expected union resistance has probably been at the root of a smaller adjustment of employment to wage increases. As a result of all these changes, wages are higher and employment is lower today than what they would have been if no institutional changes had taken place.

\subsection{The Effect of Unions on Employment Adjustment: Other Evidence}

Two lines of research were followed in order to further analyze the impact of unions on the labor market, focusing on how they affect employment adjustment. A first approach to the study of labor dynamics was carried out, looking for evidence on the impact of unions on the employment path to equilibrium. Second, the effect of unions on layoff rates was examined, performing the analysis for the whole economy and not just for the manufacturing sector.

\subsubsection{Dynamic Labor Demand}

Although the conventional wisdom is that unions lengthen the time needed for labor demand adjustment, the estimates in table 8.5 show no change between 1975-1984 and 1985-1997. It is possible that a simple before-after comparison fails to yield an accurate assessment of union impact because of other changes that were taking place in 1985-1997. In particular, the opening of the Uruguayan economy could have shortened adjustment lags at the same time that unionization was lengthening them. 
A useful approach to test for this is to consider that the speed of adjustment is itself a function of some variables related to changing the level of employment. This would imply that in equation (5), $\lambda=\lambda\left(\mathbf{a c}_{t}\right)$, with ac a vector of variables accounting for adjustment costs, that would hence interact with lagged employment (Burgess, 1988, 1989; Burgess and Dolado 1989). Variables that will be included are union density and the openness ratio. Union density should reflect implicit costs of firing workers as well as potential restrictions on the hiring of new workers. On the other hand, when there is more openness, it is quite likely that employers are subject to greater competitive pressure to compete both abroad and domestically, leading to shorter adjustment lags.

Three models are considered in table 8.8: (1) percentage union interacts with lagged employment; (2) openness interacts with lagged employment, and (3) complete interactions among percentage union, openness, and lagged employment. Linear effects are included (and interacted in the third model); otherwise, the interaction coefficients could be interpreted as proxies for linear effects omitted from the model. As shown in columns (1) and (2), the simple interactions with percentage union and openness are positive and negative, respectively, as expected, but estimated with little precision. In the model with complete interactions in column (3), the coefficient for lagged employment decreases with openness but also with percentage

Table 8.8

Estimates of Dynamic Labor Demand Equations, 1985-1997

\begin{tabular}{lccc}
\hline Variable & $(1)$ & $(2)$ & $(3)$ \\
\hline$N_{t-1}$ & 0.876 & 0.889 & 0.902 \\
& $(0.028)$ & $(0.025)$ & $(0.038)$ \\
$Q_{t}$ & 0.056 & 0.055 & 0.073 \\
$W_{t}$ & $(0.016)$ & $(0.017)$ & $(0.019)$ \\
$N_{t-1} \cdot \mathrm{UNION}$ & -0.034 & -0.032 & -0.060 \\
& $(0.015)$ & $(0.016)$ & $(0.018)$ \\
$\mathrm{UNION}$ & 0.001 & & -0.065 \\
& $(0.028)$ & & $(0.059)$ \\
$N_{t-1} \cdot$ OPEN & 0.005 & & 0.522 \\
OPEN & $(0.266)$ & & $(0.532)$ \\
OPEN $\cdot$ UNION & & -0.027 & -0.102 \\
& & $(0.024)$ & $(0.052)$ \\
$N_{t-1} \cdot$ OPEN $\cdot$ UNION & & 0.248 & 0.908 \\
SEE & & $(0.222)$ & $(0.474)$ \\
& & & -0.882 \\
& & & $(1.226)$ \\
\end{tabular}

Notes: Each equation also contains three seasonal dummies, five industry dummies, a shift parameter for the 1993-1997 period, and a constant. Each equation is estimated by 3SLS along with a wage equation that includes the same variables as in column (2) of table 8.5. 
union. In any case, neither coefficient is estimated with an acceptable degree of precision. Openness also was included in the wage-bargaining equation and consistently had a negative effect on the negotiated wage. An increase in openness from 30 to 60 percent is associated with a 1.7 percent reduction in wages.

These results are not as robust as those related to the static labor demand. However, as a first approach to employment dynamics, they do suggest that low openness in 1985-1992 led to longer lags for employment adjustment, compared to 1975-1984. However, with the increase in openness in the 1990s, the lags quickly shortened and by 1997 were shorter than they were in 1984. The overall effect for the entire 1985-1997 period is an average lag similar to that prevailing for 1975-1984, which is what we reported in table 8.5. Regarding the union effect, no conclusions can be drawn at this stage. A more complex specification for the $\lambda$ parameter might be needed, possibly accounting for different effects per industry from 1993 onward, but this is beyond the scope of this chapter.

\subsubsection{Labor Mobility}

The results in section 8.5 showed that labor demand became less responsive to changes in output and wages after the return of collective bargaining in 1985. What we do not know is if unions affect employment adjustment, given that the results in section 8.6.1 were not robust. This is an important question because the success of any policy designed to make the Uruguayan labor market more flexible will hinge on the precise mechanisms through which unions influence employment.

Unionization could be correlated with slower employment adjustment because higher wages for union members virtually eliminate all voluntary turnover. In this case, policy would have to be directed toward the bargaining power of unions. Another possibility is that union threats of wildcat strikes are sufficient to prevent management from ever conducting layoffs. In this case, policy would need to be targeted at strike behavior.

We do not have data on flows in and out of the firm that would allow us to decompose employment changes into changes in hiring, layoffs, and quits (including retirement) and get more meaningful insights into union influence. As a second-best strategy, this section examines household survey data on unemployment, quits, and layoffs. If unionization has resulted in smaller responses of employment to changes in wages or output, this effect should be echoed by some combination of a lower hiring rate, a lower quit rate, and a lower layoff rate. The emphasis here will be on the effect of unions on layoff rates. ${ }^{16}$ The analysis will be done using data for all economic sectors, not just manufacturing. Because of possible ambiguity in the responses

16. Data on new hires are only available since 1991, and quits are only observed if they result in unemployment. 
to questions about events initiating unemployment, we report results not just on layoffs, but also for all unemployment and quits resulting in unemployment. In addition to gaining insights into how unions influence employment adjustment, these results will help determine whether the conclusions for manufacturing industries are generalizable for the entire economy.

Further, there is a sizable literature on how unions affect various forms of turnover, which provides some insights into models of union behavior. It has been well established since Freeman (1980) that unionization is associated with much lower quit rates. The reasons for this correlation remain unsettled. Freeman argues that if unions provide employees with a constructive channel for settling disagreements at the workplace, they will be less likely to quit. Pay compression within unionized workplaces further reduces the quits of employees who receive the largest relative benefitsthe least skilled and the youngest. Others have argued that the correlation simply reflects the fact that the wage level is an inadequate measure for the rents received by union members; with a better measure of such rents, the impact of unions would vanish.

The impact of unions on layoff rates is more difficult to predict. In a framework where the welfare of each union member gets equal weight in the aggregate union preference function, one would expect the union to push for job security for all members. Today, however, most models presuppose the existence of politically dominant coalitions of workers within the union, usually the most senior members. In such a setting, only members of the dominant group are sheltered from layoffs. A further complicating factor is the availability and level of unemployment benefits. In the United States, unions have traditionally used layoffs by seniority and unemployment benefits to buffer their most senior members from economic fluctuations. Medoff (1979) found that layoff rates are actually higher for union members than nonunion workers. However, in the public sector in the United States, Allen (1988) found that union members were less likely to be laid off than nonunion workers. The unemployment insurance system in Uruguay provides a much lower replacement rate of income (50 percent-75 percent of the previous monthly wage, capped up to seven minimum wages) than comparable systems in the United States and the European Community, so one might expect Uruguayan unions to place a higher priority on avoiding layoffs at all costs. Unions can significantly increase the transactions costs associated with layoffs. The obligations of a nonunion employer are limited to severance pay. Unions can create additional costs, including work stoppages and slowdowns. ${ }^{17}$

17. Initially we planned to include union contract data on severance payments beyond those required by national regulations as part of this exercise. Upon studying the contracts, however, we learned that such payments are negotiated on an as-needed basis, rather than being part of an explicit contractual arrangement. These arranged payments can be quite substantial, as shown in our case study of the banking sector in Cassoni, Labadie, and Allen (1995). 
Due to the changes that have taken place, it is important to allow the effect of unions on layoffs to vary within the 1985-1997 period.

\section{Models and Data}

To estimate the impact of collective bargaining on labor mobility, ideally one would estimate hazard rates for employment, both overall and separately for quits and layoffs. There are no panel surveys of households in Uruguay and no repeated cross sections with data on completed spells of employment (or unemployment for that matter). The monthly household survey can be used to identify experienced workers who are unemployed, the sector and industry of their last job, and the reason for leaving their last job. Workers are defined as laid off if they say they lost their last job because they were "fired" or the "plant or company closed." Workers who say they were suspended from work or who are receiving unemployment insurance are excluded from this definition because of the ambiguity of whether a separation has occurred. All other separations leading to unemployment (including those who gave a reason for leaving their last job that was coded as "other") are defined as quits.

A new questionnaire was adopted for the household survey in 1991. The survey items used to identify layoffs were not changed, but the wording and number of options for quits were substantially altered. This makes it impossible to estimate models of specific types of quit behavior, such as quits for low pay or quits to return to school. As long as quits are defined broadly, there does not seem to be any significant break in the series between 1990 and 1991 (see table 8.9).

The quit-layoff distinction can be problematic empirically. Interviews with employers about the reasons for a separation would no doubt yield different answers than the household survey. In addition, the timing of the decision and the stated rationale can conceal as well as reveal, for example, workers may quit so as to avoid any stigma associated with dismissal. Accordingly, this study also examines the odds that an experienced worker is unemployed, ignoring the stated reason. This latter measure includes individuals who have been suspended or who are receiving unemployment benefits.

A clear limitation of this approach is that we do not observe cases where persons leave their job without an intervening spell of unemployment. This is unlikely to be too much of a problem with the analysis of layoffs - even with advance notice (which is not required in Uruguay); very few job losers are able to find a new position before their old one ends. Difficulties are more likely in interpreting the results on quits. Simple errors in measurement make this study less likely to reject any null hypothesis. Nonetheless, we must emphasize that the results here deal with only one dimension of quit behavior - quits followed by unemployment — and may not be generalizable to all quits. 


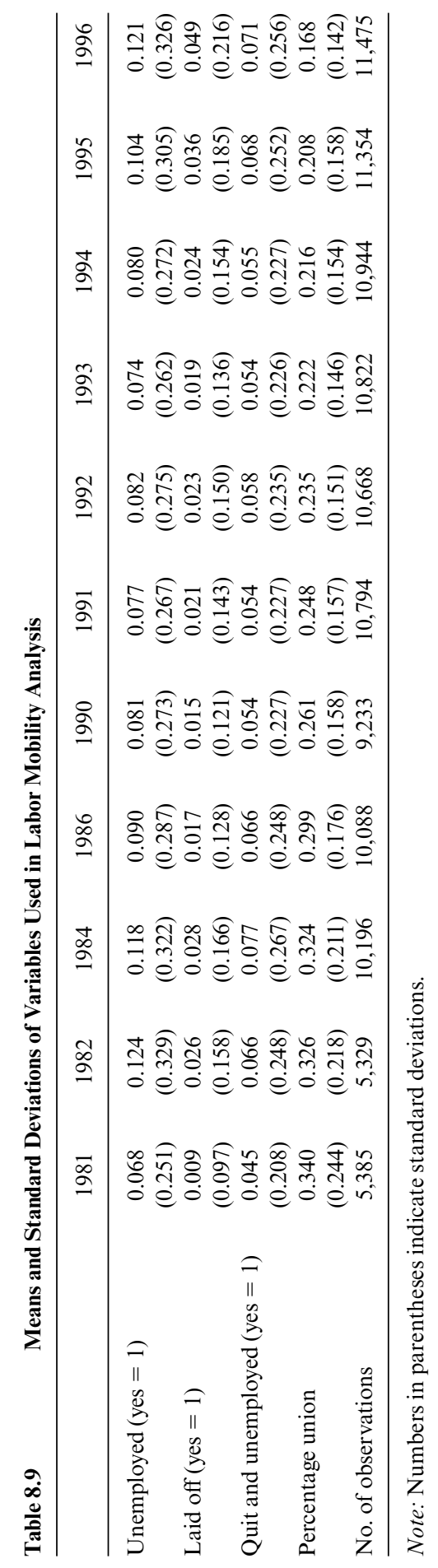


Probit equations for unemployment, quits, and layoffs are estimated over all experienced wage and salary workers in the household survey for 1981, 1982, 1984, 1986, 1990, and 1991-1996. Data for 1981 and 1982 are available only for the second half of the year. Union membership is not measured in the household survey. It was calculated as stated in section 8.4.

Other variables included in the analysis include employment in the public sector, age, age squared, sex, years of schooling, percentage informal in the last industry of employment (as indicated by lack of health coverage), ${ }^{18}$ marital status (one variable indicating married, spouse present), industry (two variables flagging manufacturing and construction-the industries with the most layoffs and unemployment), and quarter (three variables).

\section{Means and Trends}

Descriptive statistics for the main dependent and explanatory variables are reported in table 8.9.

Unemployment ranges between 7 and 12 percent over the sample period. These figures are lower than reported unemployment rates, mainly because first-time job seekers are not included in our sample (we also exclude self-employed and unpaid workers). The peak periods of unemployment are the global recession of 1982-1984 and 1995-1996, when Argentina was experiencing very high unemployment. Quit unemployment tracks the overall unemployment rate fairly closely.

The percentage of the labor force on layoff is much higher in the 1990s than in the 1980s, reaching a maximum of 5 percent in 1996. This is almost twice as large as the layoff percentage in 1982, even though the overall unemployment rates for experienced workers in the two years are both around 12 percent. Layoff percentages in 1992 and 1994 averaged 2.4 percent, despite low overall unemployment near 8 percent. In comparison, the layoff percentage in 1982 was 2.6 percent, although the unemployment rate was 12.4 percent.

Union density varies significantly through the sample period. Keep in mind that there was no collective bargaining through 1984; the values reported in table 8.9 for 1981-1986 are based on 1987 data. They are used to control for unobserved industry effects that are correlated with union density. (They vary from year to year because of changing industry composition of employment.) The mean value of percentage unionized dropped from 30 percent in 1986 to 17 percent in 1996. The decline is fairly gradual, except for a sharp four-point drop between 1995 and 1996. Union density declined by 10 or more percentage points in food and beverages, textiles and clothing, transportation and communication, and financial services in the 1990s.

18. There is legal mandatory health coverage by social security for those who work in the private sector. The Household Survey poses questions that refer specifically to health. Hence, those that report not having the mandatory coverage are defined as informal workers for the purposes of this study. 


\section{Probit Results}

The impact of unions varies markedly over the time period (see table 8.10). It is no surprise that in 1981 and 1982 the percentage union variable (which is acting in those years as a proxy for union sentiment or conditions making a sector conducive to union organization) is uncorrelated with layoff, quit, or unemployment odds.

By 1984, unions had become a powerful political force, organizing strikes and demonstrations in an effort to pressure the military government to step down. Percentage union is associated with lower odds of unemployment in 1984, all of which results from fewer quits into unemployment in unionized industries. This behavior probably reflects anticipation of a return to democracy and the restoration of collective bargaining. There is also some indication that layoff rates in sectors of the economy that were to become unionized had already become slightly lower than layoff rates in sectors that were to stay nonunion. The union coefficient in the layoff pro-

Table 8.10

Transformed Coefficients and Standard Errors of Union Coefficient in Probit Estimates

\begin{tabular}{cccc}
\hline Year & $\begin{array}{c}\text { Unemployed } \\
\text { (yes }=1)\end{array}$ & $\begin{array}{c}\text { Laid Off } \\
\text { (yes }=1)\end{array}$ & $\begin{array}{c}\text { Quit and Unemployed } \\
\text { (yes }=1)\end{array}$ \\
\hline 1981 & 0.008 & -0.006 & 0.011 \\
& $(0.024)$ & $(0.006)$ & $(0.020)$ \\
1982 & 0.059 & -0.005 & 0.029 \\
& $(0.032)$ & $(0.013)$ & $(0.024)$ \\
1984 & -0.109 & -0.016 & -0.066 \\
& $(0.026)$ & $(0.010)$ & $-0.021)$ \\
1986 & -0.065 & -0.027 & $(0.021)$ \\
& $(0.025)$ & $(0.009)$ & -0.018 \\
1990 & -0.065 & -0.011 & $(0.016)$ \\
& $(0.021)$ & $(0.006)$ & -0.023 \\
1991 & -0.032 & -0.008 & $0.016)$ \\
& $(0.019)$ & $(0.008)$ & -0.034 \\
1992 & -0.053 & -0.016 & $(0.018)$ \\
& $(0.021)$ & $(0.009)$ & -0.035 \\
1993 & -0.054 & -0.014 & $(0.016)$ \\
& $(0.019)$ & $(0.007)$ & $(0.004$ \\
1994 & -0.040 & -0.021 & -0.047 \\
& $(0.019)$ & $(0.008)$ & $(0.021)$ \\
1995 & -0.088 & -0.033 & -0.041 \\
& $(0.026)$ & $(0.013)$ & $(0.020)$ \\
1996 & -0.135 & -0.084 & \\
& $(0.027)$ & $(0.016)$ & \\
& & &
\end{tabular}

Notes: Coefficients indicate change in probability resulting from a change in fraction unionized; standard errors appear in parentheses. Control variables include fraction employed in informal sector (as proxied by health insurance coverage), employment in public sector (yes $=1$ ), age, age squared, male, years of schooling, married, industry (dummies for manufacturing and construction), and quarter. 
bit increased from -0.005 in 1982 to -0.016 in 1984 (although the latter effect is not estimated with a high degree of precision).

The picture changes further by 1986, when percentage union (based on 1987 data, as in 1981-1982 and 1984) is now strongly associated with lower layoff odds. Unionization is associated with a 1 to 2 percentage point reduction in layoff odds in most years between 1986 and 1994. This may seem modest in absolute terms, but keep in mind that the mean layoff rate varies between 1.5 and 2.4 percent over this period. Assuming a mean unionization of 25 percent, a mean layoff rate of 2 percent, and a union-nonunion difference in layoff rates of 1.5 percent, this implies that the odds of layoff for a union worker are 0.9 percent versus 2.4 percent for a nonunion worker.

Even though union density was declining and unionized companies were more exposed to global competition, the estimated effect of unions on layoffs actually stayed quite strong in 1995 and 1996. The aggregate layoff rate increased to 3.6 percent in 1995 and 4.9 percent in 1996. The impact of unions increased to 3.3 percent in 1995. Based on this coefficient and the means of the key variables, this result implies that the layoff odds for a union worker were 1.0 percent versus 4.3 percent for a nonunion worker. Compared to previous years, all of the increase in layoff risk was borne by nonunion workers. The results for 1996 are too strong; the union coefficient in the layoff and unemployment probits is larger than the mean layoff and unemployment rate.

The increase in the union-nonunion gap in layoff rates might seem puzzling in light of the decline in union density. One might argue that union members are self-selecting into firms with lower turnover, but the model controls for the odds that a worker is in the informal sector, where mobility would be greatest. Another possibility is that the remaining union workers have higher tenure (relative to nonunion workers) in 1995 and 1996 than in previous years, but the data show that this difference (1.2 years) is the same in 1995 and 1996 as in 1991-1994. The most logical possibility is that the unions that did survive until 1995-1996 were the most powerful ones. Layoff rates in those firms stayed at 1 percent, while those in the nonunion sector increased dramatically.

The overall implication of these results is that the layoff odds of a worker in a unionized sector were less than 1 percent from 1986 through 1996. Any fluctuation in aggregate layoff rates reflected adjustments by nonunion employers.

Even with near-zero layoff rates, unionized employers still have some freedom to make changes in employment if the quit rate is sufficiently high. This is not the case in Uruguay. Instead, employer flexibility in unionized enterprises is especially hampered by very low quit rates. The size of the effect varies from year to year between 1984 and 1994, but in most years it is close to a 3 percentage point difference in the odds of quitting and becoming unemployed between workers in a fully unionized and a fully nonunion industry. The impact of unions on quits resulting in unemployment rises in 1995 and 1996. 
In summary, the change in labor demand elasticities observed at the industry level of aggregation is no optical illusion. What we see at the micro, individual-worker level matches what we see at the industry level-employment now adjusts less than it would have in the absence of unions. What makes these results all the more convincing is that the same measure of union density used for 1986-1996 has no effect on unemployment, quits, or layoffs when applied retrospectively to 1981-1982. Effects on quits (and a weak effect on layoffs) begin to appear in 1984 as unions became more active, but the full effect on layoffs is not present until bargaining had officially resumed.

\subsection{Conclusions}

This study has examined a unique situation in Uruguay where before-after comparisons about the impact of collective bargaining can be made. During the period under study there were three distinct regimes: (1) 1975-1984, when bargaining was banned, (2) 1985-1991, when there was tripartite bargaining, and (3) 1992-1997, when there was bargaining without government involvement. During the third regime, the economy became much more open, which would presumably also have an effect on bargaining results.

We have reported strong evidence of a change in economic behavior after 1985. Recursive residuals show structural shifts in five of six industries, with the shifts coming at about the same time as the regime changes. These breaks are also significant in a model specified in differences. Cointegration of employment, output, and labor costs is rejected for the whole period. Wages are exogenous to employment before 1985, but not afterwards.

Based on this evidence we estimated a standard IVE labor demand model for 1975-1984 and a right-to-manage bargaining model for 19851997. The results showed that the long-run wage elasticity of labor demand and the employment-output elasticity fell sharply. Although there was no overall change in the amount of time needed for employment adjustment, a detailed examination of the 1985-1997 period suggested that the increased lag created by collective bargaining may have been offset by a shorter lag created by greater openness.

The bargaining model results indicated that unions significantly raised wages in 1985-1992. Afterward, the change in bargaining structure and increased openness had a pronounced effect on bargaining outcomes. Labor demand shifted to the left from 1993 onward. The union wage differential vanished in 1993 in four industries where there were sharp increases in openness and sharp declines in percentage union. Wages in the chemical and oil industry were not affected very much. Although that industry became more open, it has remained heavily unionized, which is no doubt a consequence of state ownership.

What would have happened to wages and employment had the ban on unions been maintained? To build a counterfactual, we estimated an ARIMA $(4,1,0)$ model of wages for 1975-1984, which was used to project a 
wage path through 1997. Actual wages have been significantly higher than the simulated "nonunion" wage, based on average values for 1985-1997. Taking into account the higher wage level and the reduced elasticities, employment in 1985-1997 was lower than it would have been if unions had not returned.

Because of possible skepticism regarding the use of industry rather than establishment data, we also examined the effect of unionization on turnover, using household survey data. These results showed that workers in unionized industries were much less likely to be laid off starting in 1985 than workers in nonunion industries. Before 1985, no such pattern is present, indicating that unionization is not acting as a proxy for other industry characteristics associated with high layoff odds.

The following picture emerges from these results. Unions returned on the scene as a political and economic force in 1985, and for two years more than half of Uruguay's workers were union members. Union density settled down to about 40 percent in 1987-1992, and unions were able to successfully negotiate higher wages and were able to protect against job loss by reducing employment elasticities. It would be useful to know the precise mechanisms through which unions reduced employment adjustment. It is doubtful that unions had much effect on consumer choices, because no steps were made to expand state ownership or deliberalize trade when unions returned. The most likely channels through which unions had an impact were restrictive work practices and the threat of strikes or slowdowns in situations where layoffs were thought possible.

In the 1990s, the end of tripartite bargaining, trade liberalization, and the recession in Argentina forced unions to make compromises at the bargaining table. Faced with an adverse shift in labor demand, unions reduced their wage demands to preserve jobs. Percentage union declined to 20 percent, as many unionized establishments were no longer economically competitive and others were forced to increase productivity to survive. When a few more years of data become available, it would be fruitful to determine if elasticities had returned to their 1975-1984 values.

This study has focused on wage and employment effects of unions. To get a more complete view of the overall impact of unions on the Uruguayan economy, further study of strikes would be necessary to get a lower-bound estimate of work hours lost to strikes. These would include not only strikes against employers in the context of bargaining over wages, but also strikes - including employer-specific, sector-specific, and general strikesthat take place when a bargaining agreement is in effect.

Finally, this study has not discussed the benefits that result from successful union-management cooperation. Future work should carefully examine this matter, not only because of a need to focus as carefully as possible on labor demand and bargaining, but also because the structure of the system of labor relations has become increasingly decentralized in Uruguay, and unions are apparently changing their utility function when they bargain at the firm level under competitive pressures. 


\section{Appendix}

Table 8A.1

Tests of Order of Integration per Manufacturing Industry, 1975-1997

\begin{tabular}{|c|c|c|c|c|c|c|}
\hline Lag & Ind.31 & Ind.32 & Ind.34 & Ind. 35 & Ind.36 & Ind.38 \\
\hline \multicolumn{7}{|c|}{ Employment: level $(N)^{\mathrm{a}}$} \\
\hline 2 & -1.1390 & -0.76966 & -0.76308 & -0.90884 & -1.2061 & -1.1304 \\
\hline 1 & -1.3592 & -0.37021 & -0.62265 & -0.44888 & -1.1309 & -1.0459 \\
\hline 0 & -1.4418 & 0.065646 & -0.41783 & -0.61987 & -1.5025 & -0.71382 \\
\hline \multicolumn{7}{|c|}{ Employment: first differences $(\Delta N)^{\mathrm{b}}$} \\
\hline 2 & $-6.2857 * *$ & $-3.9358 * *$ & -4.5668 & $-4.6456^{* *}$ & $-5.3364 * *$ & $-3.9579 * *$ \\
\hline 1 & $-7.9173 * *$ & $-4.8130 * *$ & $-5.9609 * *$ & $-5.1050 * *$ & $-6.8421 * *$ & $-5.8053 * *$ \\
\hline \multirow[t]{3}{*}{0} & $-9.8103^{* *}$ & $-7.5615^{* *}$ & $-8.5221^{* *}$ & $-10.638^{* *}$ & $-11.078^{* *}$ & $-7.9268 * *$ \\
\hline & \multicolumn{2}{|c|}{ Model 1} & Model 2 & \multicolumn{3}{|c|}{ Model 1} \\
\hline & Ind. 31 & Ind.32 & Ind.34 & Ind. 35 & Ind.36 & Ind .38 \\
\hline \multicolumn{7}{|c|}{ Production: level $(Q)^{\mathrm{c}}$} \\
\hline 2 & -1.3540 & -2.5795 & -1.9669 & -2.5885 & -2.1739 & -2.5012 \\
\hline 1 & -2.1006 & -2.6076 & -2.1029 & -2.7678 & -2.0751 & -2.2671 \\
\hline \multirow[t]{2}{*}{0} & -3.3231 & -2.5531 & -2.4932 & -3.4557 & -2.5633 & -2.2659 \\
\hline & Ind.31 & Ind.32 & Ind.34 & Ind.35 & Ind.36 & Ind .38 \\
\hline \multicolumn{7}{|c|}{ Production: first differences $(\Delta Q)^{\mathrm{d}}$} \\
\hline 2 & $-12.875^{* *}$ & $-9.3050 * *$ & $-6.6666 * *$ & $-5.6461 * *$ & $-6.9455^{* *}$ & $-7.3525^{* *}$ \\
\hline 1 & $-9.9075^{* *}$ & $-9.3008 * *$ & $-8.4027^{* *}$ & $-8.7462^{* *}$ & $-8.6921^{* *}$ & $-8.2238^{* *}$ \\
\hline 0 & $-15.957 * *$ & $-11.736^{* *}$ & $-11.903^{* *}$ & $-11.808 * *$ & $-11.269^{* *}$ & $-11.540 * *$ \\
\hline \multicolumn{7}{|c|}{ Real Labor Costs: level $(W)^{\mathrm{e}}$} \\
\hline 2 & -1.6274 & -1.4101 & -1.1787 & -0.66944 & -1.6212 & -0.80691 \\
\hline 1 & -1.0999 & -1.4270 & -1.5039 & -0.77055 & -1.6527 & -1.4528 \\
\hline 0 & -1.5100 & -2.1114 & -1.5233 & -1.1714 & -1.9015 & -2.0100 \\
\hline \multicolumn{7}{|c|}{ Real Labor Costs: first differences $(\Delta W)^{\mathrm{f}}$} \\
\hline 2 & $-6.3493^{* *}$ & $-7.1240^{* *}$ & $-7.2240^{* *}$ & $-7.2307^{* *}$ & $-6.4613^{* *}$ & $-9.2235^{* *}$ \\
\hline 1 & $-5.7181 * *$ & $-7.6787 * *$ & $-7.7919^{* *}$ & $-7.6088^{* *}$ & $-7.1191 * *$ & $-10.307^{* *}$ \\
\hline 0 & $-11.331 * *$ & $-12.536^{* *}$ & $-9.5372 * *$ & $-11.935^{* *}$ & $-10.601^{* *}$ & $-12.048 * *$ \\
\hline
\end{tabular}

Note: Industries reported are: food, beverage, and tobacco (31); textiles and apparel (32); paper (34); chemicals (35); nonmetallic minerals (36); and metal products (38).

aUnit-root tests 1975 (4) to 1997 (4) Augmented Dickey-Fuller statistic (t-adf). Critical values: $5 \%=-2.894 ; 1 \%=-3.505$; Constant included.

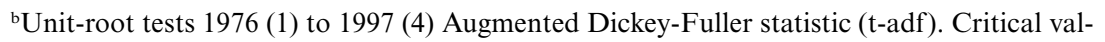
ues: $5 \%=-2.894 ; 1 \%=-3.505$; Constant included.

cUnit-root tests 1975 (4) to 1997 (4) Augmented Dickey-Fuller statistic (t-adf). Critical values Model 1: $5 \%=-3.46 ; 1 \%=-4.064$; Constant and Trend and Seasonals included. Critical values Model 2: $5 \%=-2.894 ; 1 \%=-3.505$; Constant included.

${ }^{\mathrm{d}}$ Unit-root tests 1976 (1) to 1997 (4) Augmented Dickey-Fuller statistic (t-adf). Critical values: $5 \%=-2.894 ; 1 \%=-3.505$; Constant included.

eUnit-root tests 1975 (4) to 1997 (4) Augmented Dickey-Fuller statistic (t-adf). Critical values: $5 \%=-2.894 ; 1 \%=-3.505$; Constant included.

${ }^{\mathrm{f}}$ Unit-root tests 1976 (1) to 1997 (4) Augmented Dickey-Fuller statistic (t-adf). Critical values: $5 \%=-2.894 ; 1 \%=-3.505$; Constant included. 


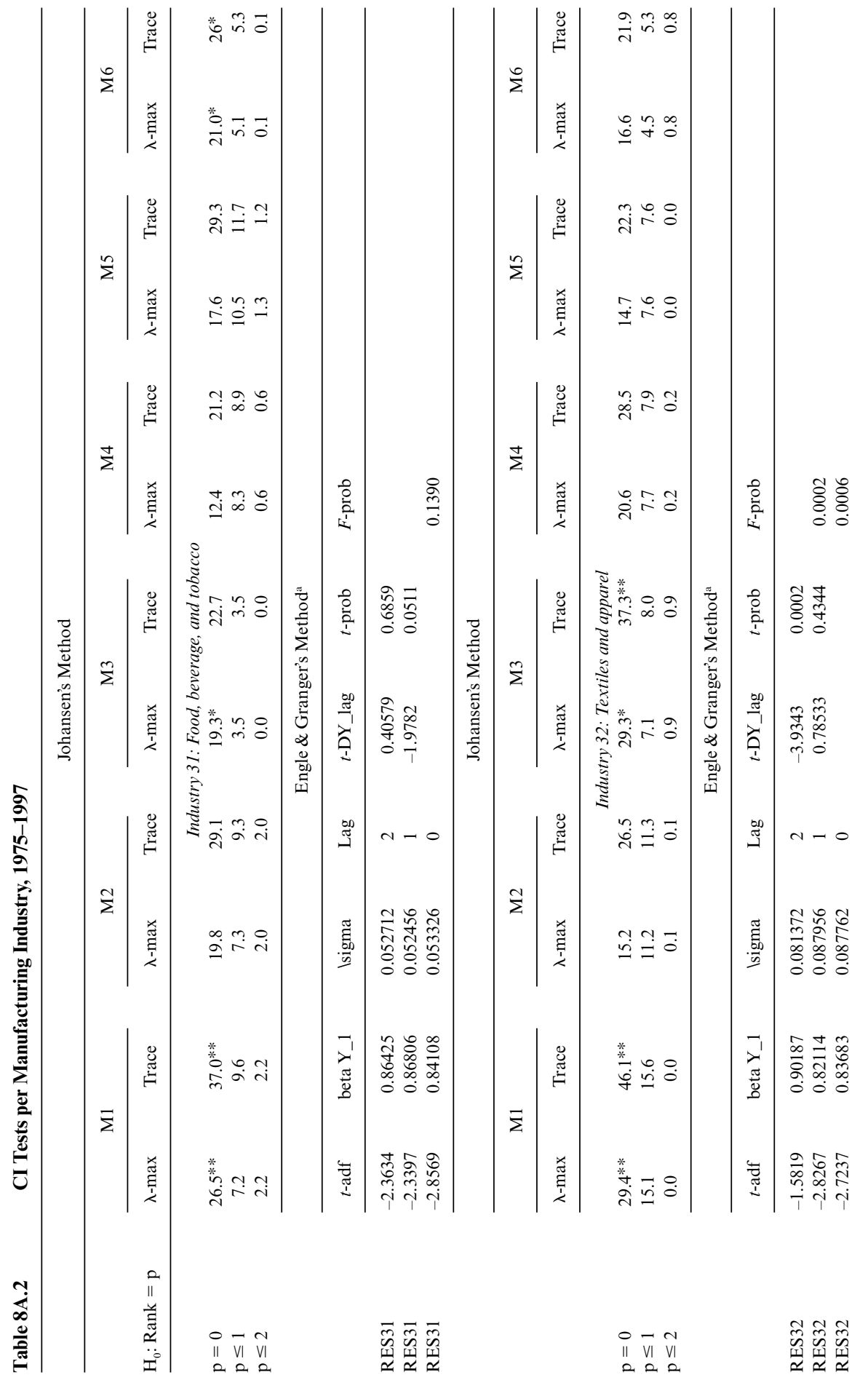



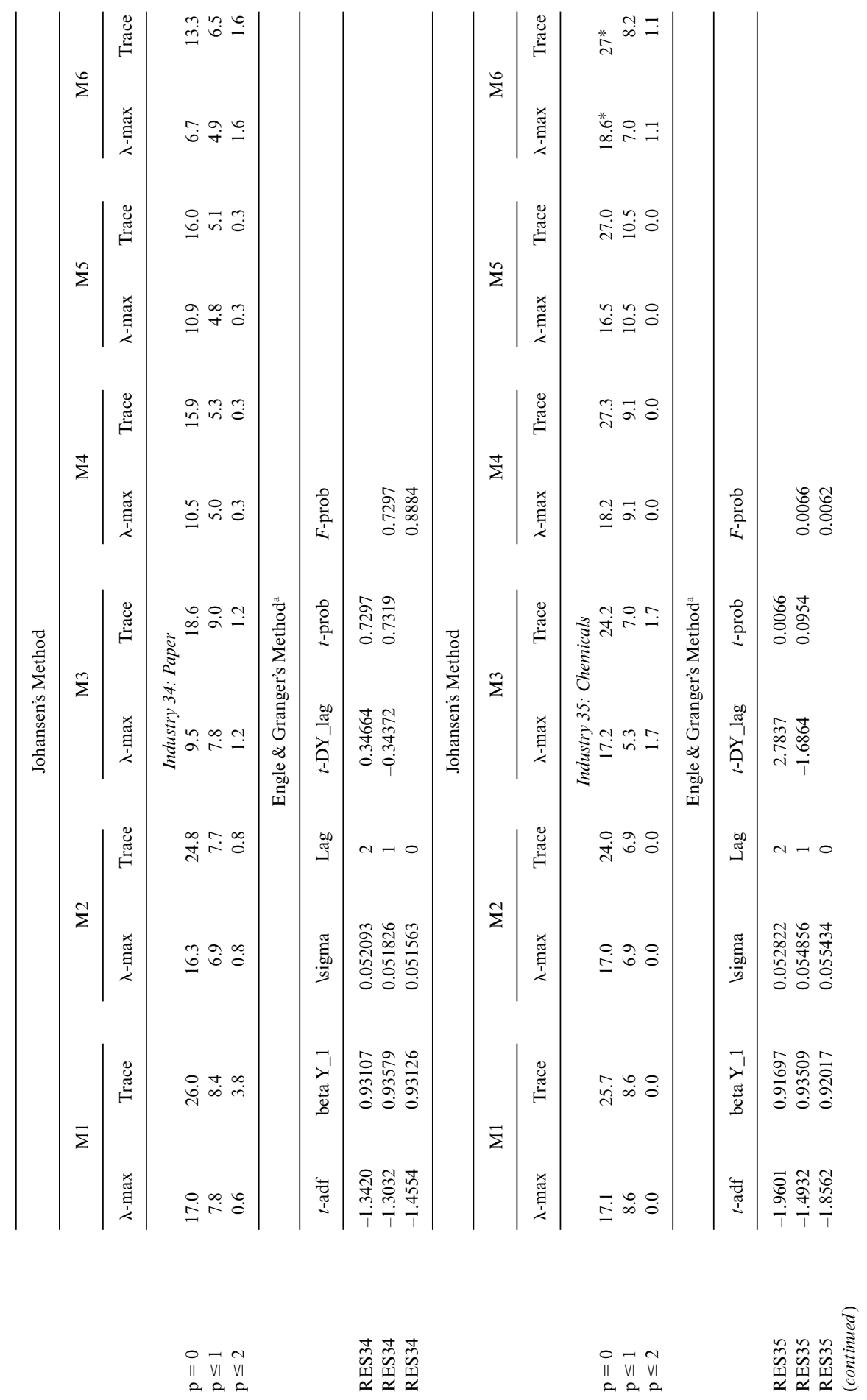


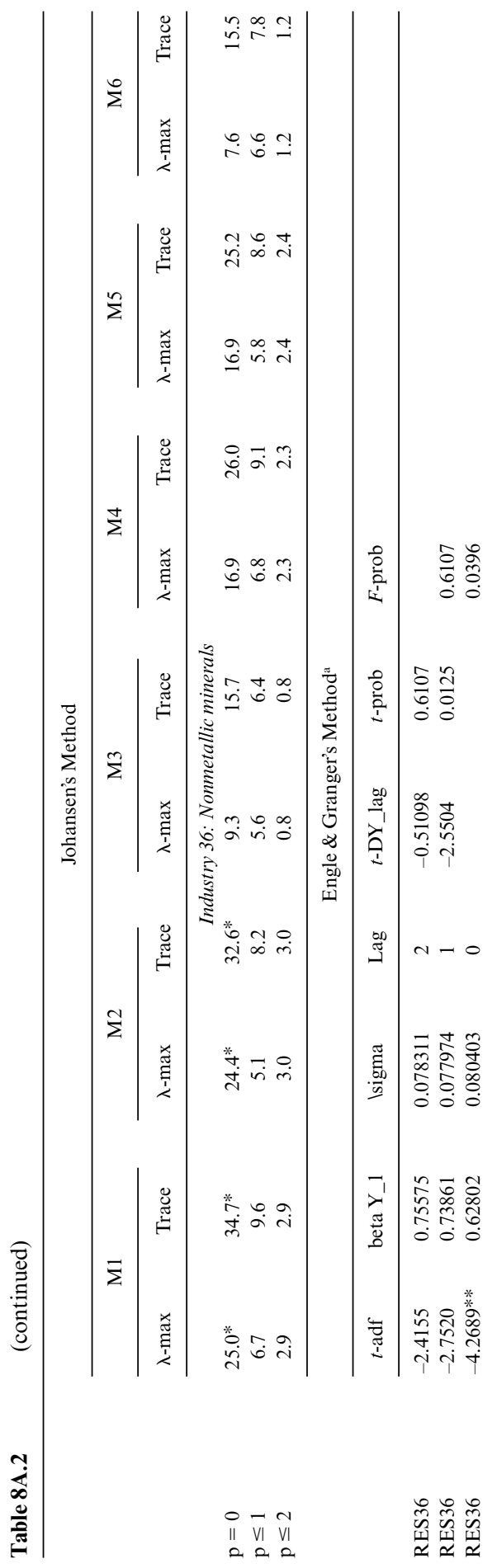




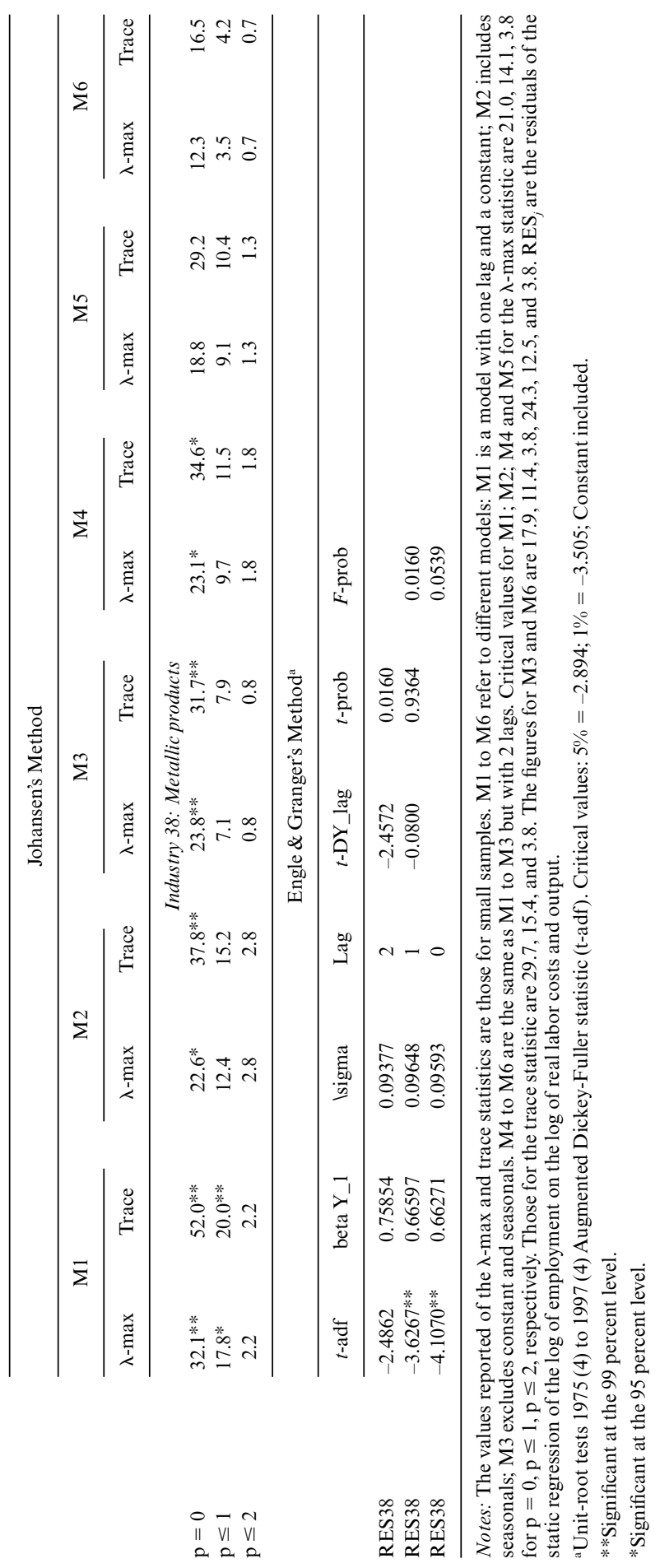




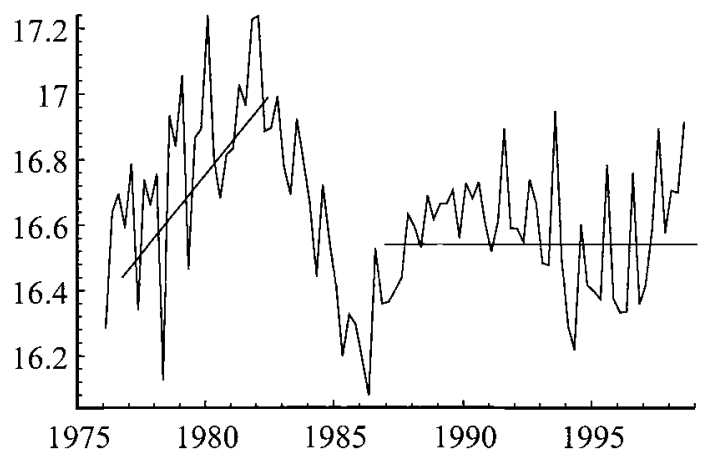

Fig. 8A.1 CI relation 1975-1997: Food, beverage, and tobacco

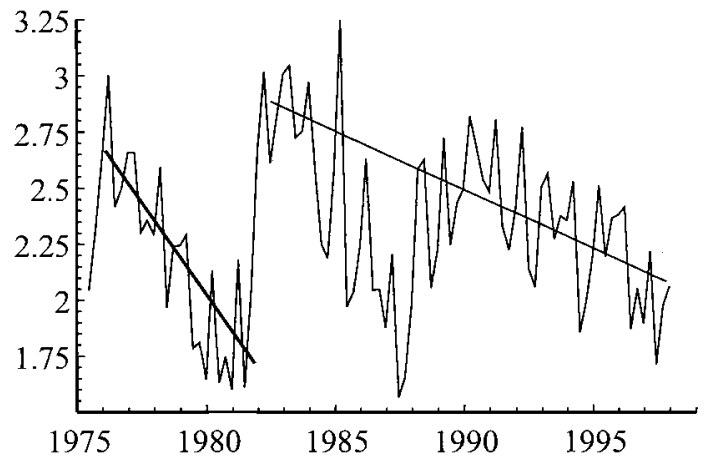

Fig. 8A.2 CI relation 1975-1997: Textiles and apparel

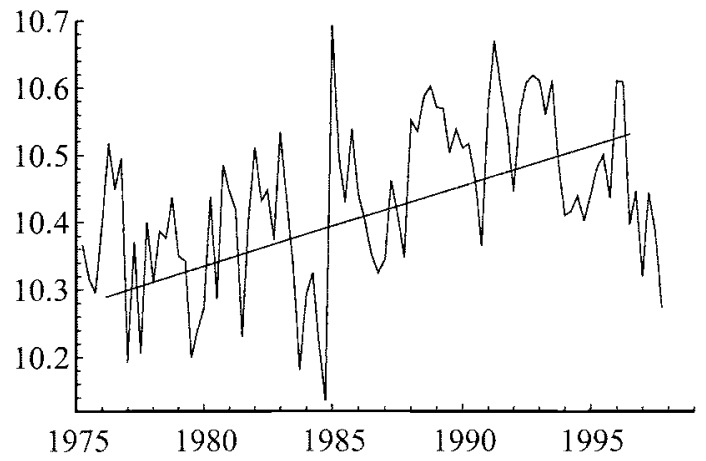

Fig. 8A.3 CI relation 1975-1997: Nonmetallic minerals 


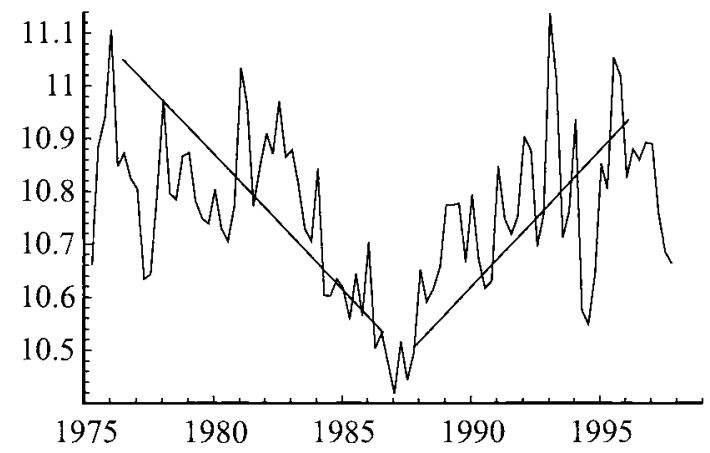

Fig. 8A.4 CI relation 1975-1997: Metal products

Table 8A.3

\begin{tabular}{|c|c|c|c|c|c|c|}
\hline Lag & Ind.31 & Ind.32 & Ind.34 & Ind. 35 & Ind.36 & Ind. 38 \\
\hline \multicolumn{7}{|c|}{ Employment: level $(N)^{\mathrm{a}}$} \\
\hline 2 & -2.5950 & -1.6086 & -1.2078 & -1.2582 & -0.83448 & -1.2016 \\
\hline 1 & -2.7889 & -1.3369 & -1.1917 & -1.1657 & -0.85303 & -1.0131 \\
\hline 0 & -2.7786 & -0.87525 & -1.2005 & -1.1396 & -1.2904 & -0.40892 \\
\hline \multicolumn{7}{|c|}{ Employment: first differences $(\Delta N)^{\mathrm{a}}$} \\
\hline 2 & $-3.5006^{*}$ & $-2.3858^{\mathrm{T}}$ & $-3.1008^{*}$ & -2.7929 & $-3.3449 *$ & -2.2757 \\
\hline 1 & $-4.7977^{* *}$ & -2.7784 & $-4.0736^{* *}$ & $-3.3230^{*}$ & $-4.7078^{* *}$ & -2.9124 \\
\hline 0 & $-5.9422 * *$ & $-3.9935^{* *}$ & $-5.9520 * *$ & $-5.3326^{* *}$ & $-7.8115^{* *}$ & $-3.8907^{* *}$ \\
\hline \multicolumn{7}{|c|}{ Production: level $(Q)^{\mathrm{a}}$} \\
\hline 2 & -1.3551 & -1.5597 & -1.0378 & -1.5105 & -1.2428 & -1.3483 \\
\hline 1 & -1.5006 & -1.7065 & -1.0796 & -1.9170 & -1.1518 & -1.1211 \\
\hline 0 & $-3.5859^{*}$ & -1.8756 & -1.3054 & -2.1261 & -1.3826 & -1.4192 \\
\hline \multicolumn{7}{|c|}{ Production: first differences $(\Delta Q)^{\mathrm{a}}$} \\
\hline 2 & $-7.0006^{* *}$ & $-4.5957 * *$ & $-3.1842^{* *}$ & $-3.6610^{* *}$ & $-4.1848^{* *}$ & $-3.8934 * *$ \\
\hline 1 & $-5.8296 * *$ & $-4.8931 * *$ & $-4.4946^{* *}$ & $-5.3628 * *$ & $-4.1581^{* *}$ & $-3.9342 * *$ \\
\hline 0 & $-11.328 * *$ & $-6.5990 * *$ & $-6.8692 * *$ & $-6.5669 * *$ & $-6.7829^{* *}$ & $-7.2999 * *$ \\
\hline \multicolumn{7}{|c|}{ Real Labor Costs: level $(W)^{\mathrm{a}}$} \\
\hline 2 & -1.9026 & -1.5492 & -1.2954 & -1.2465 & -1.6269 & -1.2547 \\
\hline 1 & -1.4888 & -1.0608 & -1.6641 & -1.2532 & -1.3242 & -1.5461 \\
\hline 0 & -1.7139 & -1.7121 & -1.5443 & -1.7968 & -1.4835 & -1.8132 \\
\hline \multicolumn{7}{|c|}{ Real Labor Costs: first differences $(\Delta W)^{\mathrm{a}}$} \\
\hline 2 & $-4.1317 * *$ & $4.5866^{* *}$ & $-5.2300 * *$ & $-4.6311 * *$ & $-3.4348^{*}$ & $-5.0862 * *$ \\
\hline 1 & $-3.7696^{* *}$ & $-4.3153^{* *}$ & $-5.0854 * *$ & $-4.8072 * *$ & $-3.6439^{* *}$ & $-5.5376^{* *}$ \\
\hline 0 & $-6.6798 * *$ & $-8.0047^{* *}$ & $-5.5840 * *$ & $-8.1063^{* *}$ & $-6.5290^{* *}$ & $-7.1038^{* *}$ \\
\hline
\end{tabular}

Note: Industries reported are: food, beverage, and tobacco (31); textiles and apparel (32); paper (34); chemicals (35); nonmetallic minerals (36); and metal products (38).

${ }^{a}$ Unit-root tests 1976 (1) to 1984 (4). Augmented Dickey-Fuller statistic (t-adf). Critical values: $5 \%=-2.945 ; 1 \%=-3.623$; Constant included. 


\begin{tabular}{|c|c|c|c|c|c|c|}
\hline Lag & Ind.31 & Ind.32 & Ind.34 & Ind.35 & Ind.36 & Ind.38 \\
\hline \multicolumn{7}{|c|}{ Employment: level $(N)^{\mathrm{a}}$} \\
\hline 2 & 0.46044 & 0.52536 & 0.52631 & 0.23815 & -0.85312 & -0.19819 \\
\hline 1 & 0.071919 & 0.73045 & 0.47858 & 0.84976 & -0.72559 & -0.35062 \\
\hline 0 & -0.15768 & 0.56007 & 0.90892 & 0.26647 & -0.68648 & 0.43073 \\
\hline \multicolumn{7}{|c|}{ Employment: first differences $(\Delta N)^{\mathrm{b}}$} \\
\hline 2 & $-5.4181 * *$ & $-3.1749 *$ & $-3.1094 *$ & $-3.4679 *$ & $-3.8123 * *$ & $-3.3249 *$ \\
\hline 1 & $-6.4158^{* *}$ & $-4.3344 * *$ & $-4.2772 * *$ & $-3.8352 * *$ & $-4.2025 * *$ & $-5.3928^{* *}$ \\
\hline \multirow[t]{3}{*}{0} & $-7.8121 * *$ & $-7.3548 * *$ & $-5.5190 * *$ & $-9.3899 * *$ & $-6.6537 * *$ & $-7.1566^{* *}$ \\
\hline & Model 1 & Model 2 & & Model 3 & & Model 2 \\
\hline & Ind.31 & Ind.32 & Ind.34 & Ind.35 & Ind.36 & Ind.38 \\
\hline \multicolumn{7}{|c|}{ Production: level $(Q)^{\mathrm{b}}$} \\
\hline 2 & -0.75192 & -1.2447 & -2.9285 & -1.9864 & $-4.2071 * *$ & -2.1404 \\
\hline 1 & -1.5892 & -1.5003 & -2.6061 & -1.9425 & $-3.9310^{*}$ & -2.1935 \\
\hline \multirow[t]{3}{*}{0} & -2.6469 & -1.6600 & -3.3922 & -2.6681 & $-4.1709 * *$ & -2.3594 \\
\hline & Ind.31 & Ind.32 & Ind.34 & Ind. 35 & Ind.36 & Ind.38 \\
\hline & \multicolumn{6}{|c|}{ Production: first differences $(\Delta Q)^{\mathrm{c}}$} \\
\hline 2 & $-13.804 * *$ & $-8.5948 * *$ & $-5.3499 * *$ & $-3.9875^{* *}$ & $-5.6954 * *$ & \\
\hline 1 & $-8.6737^{* *}$ & $-7.4293 * *$ & $-6.0758 * *$ & $-6.3471 * *$ & $-7.0047^{* *}$ & \\
\hline \multirow[t]{2}{*}{0} & $-10.568^{* *}$ & $-9.2444 * *$ & $-8.7901 * *$ & $-8.9858 * *$ & $-8.4481^{* *}$ & \\
\hline & Ind.31 & Ind.32 & Ind.34 & Ind. 35 & Ind.36 & Ind.38 \\
\hline \multicolumn{7}{|c|}{ Real Labor Costs: level $(W)^{\mathrm{a}}$} \\
\hline 2 & -0.91189 & -0.79368 & -0.28570 & -1.2903 & -0.39377 & -0.16091 \\
\hline 1 & -1.0367 & -0.87610 & -0.27960 & -1.3079 & -0.75799 & -0.63152 \\
\hline 0 & -1.1111 & -1.1709 & -0.37651 & -1.3448 & -1.0533 & -1.2518 \\
\hline \multicolumn{7}{|c|}{ Real Labor Costs: first differences $(\Delta W)^{\mathrm{a}}$} \\
\hline 2 & $-4.8027 * *$ & $-5.8573 * *$ & $-3.5825 * *$ & $-4.7689 * *$ & $-6.4608 * *$ & $-9.4354 * *$ \\
\hline 1 & $-4.5204^{* *}$ & $-6.6026^{* *}$ & $-5.0680 * *$ & $-5.3096^{* *}$ & $-6.8041^{* *}$ & $-9.1931^{* *}$ \\
\hline 0 & $-11.318^{* *}$ & $-9.6385 * *$ & $-7.2193^{* *}$ & $-7.5302^{* *}$ & $-8.0805^{* *}$ & $-9.8846^{* *}$ \\
\hline \multicolumn{7}{|c|}{ Alternative Income: level $(A W)^{\mathrm{a}}$} \\
\hline 2 & -1.0622 & -0.26599 & -0.68071 & -1.5105 & -1.2264 & -0.31812 \\
\hline 1 & -1.0977 & -0.27479 & -0.70182 & -1.5243 & -1.2636 & -0.50304 \\
\hline 0 & -1.3744 & -0.53359 & -0.58792 & -1.5418 & -1.3169 & -0.75351 \\
\hline \multicolumn{7}{|c|}{ Alternative Income: first differences $(\Delta A W)^{\mathrm{a}}$} \\
\hline 2 & $-5.3632^{* *}$ & $-5.0075^{* *}$ & $-3.6446^{* *}$ & $-4.2448 * *$ & $-5.0124 * *$ & $-6.1520 * *$ \\
\hline 1 & $-5.1457 * *$ & $-5.5917 * *$ & $-4.6648 * *$ & $-4.8143 * *$ & $-5.3230 * *$ & $-6.6413^{* *}$ \\
\hline 0 & $-11.588^{* *}$ & $-8.8841 * *$ & $-6.2868 * *$ & $-6.7643 * *$ & $-7.3100 * *$ & $-8.3432 * *$ \\
\hline
\end{tabular}


(continued)

\begin{tabular}{|c|c|c|c|c|c|c|}
\hline Lag & Ind.31 & Ind.32 & Ind.34 & Ind.35 & Ind.36 & Ind.38 \\
\hline \multicolumn{7}{|c|}{ Open: level $(O P E N)^{\mathrm{a}}$} \\
\hline 2 & -1.9511 & -0.71192 & -0.40513 & -2.6096 & -0.83810 & 0.037784 \\
\hline 1 & -1.8791 & -0.75411 & -0.42541 & -2.6449 & -0.90096 & -0.074127 \\
\hline 0 & -1.8177 & -0.79349 & -0.44497 & -2.6798 & -0.95574 & -0.16839 \\
\hline \multicolumn{7}{|c|}{ Open: first differences $(\triangle O P E N)^{\mathrm{a}}$} \\
\hline 2 & $-3.8378 * *$ & $-4.0946^{* *}$ & $-3.9638 * *$ & $-4.0242 * *$ & $-4.6335 * *$ & $-4.5125^{* *}$ \\
\hline 1 & $-4.7509 * *$ & $-4.9832 * *$ & $-4.8664 * *$ & $-4.9206^{* *}$ & $-5.4326^{* *}$ & $-5.3361 * *$ \\
\hline 0 & $-6.7895^{* *}$ & $-7.0051^{* *}$ & $-6.8980 * *$ & $-6.9481 * *$ & $-7.3932 * *$ & $-7.3130 * *$ \\
\hline \multicolumn{7}{|c|}{ Union: level $(U N I O N)^{a}$} \\
\hline 2 & -0.40374 & -1.6373 & -2.8522 & -2.1880 & $-2.9658^{*}$ & -2.7446 \\
\hline 1 & -1.0067 & -1.8707 & -2.8877 & -2.2243 & $-3.0142 *$ & -2.7748 \\
\hline 0 & -0.87189 & -1.9477 & -2.9067 & -2.1657 & $-3.2859 *$ & -2.7978 \\
\hline \multicolumn{7}{|c|}{ Union: first differences $(\triangle U N I O N)^{\mathrm{a}}$} \\
\hline 2 & $-4.6465^{* *}$ & $-4.3718^{* *}$ & $-4.2272 * *$ & $-3.3584^{*}$ & $-3.6973 * *$ & $-3.3502 *$ \\
\hline 1 & $-6.4368 * *$ & $-6.2137 * *$ & $-4.7436 * *$ & $-5.0175^{* *}$ & $-3.9382 * *$ & $-4.7011 * *$ \\
\hline 0 & $-6.3998 * *$ & $-7.2938^{* *}$ & $-6.5521 * *$ & $-6.8383 * *$ & $-5.2671 * *$ & $-7.1536^{* *}$ \\
\hline
\end{tabular}

Note: See table 8A.3.

${ }^{a}$ Unit-root tests 1986 (1) to 1997 (4) Augmented Dickey-Fuller statistic (t-adf). Critical values: $5 \%=-2.923 ; 1 \%=-3.571$; Constant included.

${ }^{b}$ Unit-root tests 1986 (1) to 1997 (4) Augmented Dickey-Fuller statistic (t-adf). Critical values Model 1: $5 \%=-2.923 ; 1 \%=-3.571$; Constant included. Critical values Model 2: $5 \%=$ $-2.923 ; 1 \%=-3.571$; Constant and Seasonals included. Critical values Model 3: $5 \%=$ $-3.504 ; 1 \%=-4.158$; Constant and Trend and Seasonals included.

'Unit-root tests 1986 (1) to 1997 (4) Augmented Dickey-Fuller statistic (t-adf). Critical values Model 1: $5 \%=-2.923 ; 1 \%=-3.571$; Constant included.

**Significant at the 99 percent level.

* Significant at the 95 percent level. 
Table 8A.5

CI Tests per Manufacturing Industry, 1975-1984 and 1985-1997

\begin{tabular}{|c|c|c|c|c|c|c|c|c|}
\hline \multicolumn{4}{|c|}{ Industry 31 : Food, beverage, and tobacco } & \multicolumn{5}{|c|}{ Industry 34: Paper } \\
\hline \multirow[t]{2}{*}{ Residual } & \multicolumn{3}{|l|}{ t-adf } & \multirow{2}{*}{\multicolumn{2}{|c|}{$\begin{array}{l}\mathrm{H}_{0}: \\
\text { Rank }=\mathrm{p} \quad \lambda \text {-max }\end{array}$}} & \multirow{2}{*}{$95 \%$} & \multirow{2}{*}{ Trace } & \multirow{2}{*}{$95 \%$} \\
\hline & \multicolumn{3}{|c|}{$1975-1984^{\mathrm{a}}$} & & & & & \\
\hline \multirow{6}{*}{$\begin{array}{l}\text { RES31 } \\
\text { RES31 } \\
\text { RES31 }\end{array}$} & \multicolumn{3}{|l|}{-2.6059} & \multicolumn{5}{|c|}{$1975-1984$} \\
\hline & -2.6875 & & & \multirow{5}{*}{$\begin{array}{l}p=0 \\
p \leq 1 \\
p \leq 2\end{array}$} & \multirow{3}{*}{$\begin{array}{l}23.1^{*} \\
3.11 \\
0.003218\end{array}$} & \multirow{3}{*}{$\begin{array}{r}21.0 \\
14.1 \\
3.8 \\
\end{array}$} & \multirow{3}{*}{$\begin{array}{l}26.22 \\
3.113 \\
0.00321\end{array}$} & \multirow{3}{*}{$\begin{array}{r}29.7 \\
15.4 \\
3.8\end{array}$} \\
\hline & $-3.0998^{*}$ & & & & & & & \\
\hline & \multirow{2}{*}{$\begin{array}{c}\text { M1 } \\
\text { (t-adf) } \\
\end{array}$} & \multirow{2}{*}{$\begin{array}{c}\mathrm{M} 2 \\
\text { (t-adf) }\end{array}$} & \multirow{2}{*}{$\begin{array}{c}\text { M3 } \\
\text { (t-adf) }\end{array}$} & & & & & \\
\hline & & & & & \multirow{2}{*}{$\begin{array}{c}\text { M1 } \\
\text { (t-adf) }\end{array}$} & \multirow{2}{*}{$\begin{array}{c}\text { M2 } \\
\text { (t-adf) }\end{array}$} & \multirow{2}{*}{$\begin{array}{c}\text { M3 } \\
\text { (t-adf) }\end{array}$} & \\
\hline & \multicolumn{3}{|c|}{$1985-1997$} & & & & & \\
\hline \multirow{4}{*}{$\begin{array}{l}\text { RES31 } \\
\text { RES31 } \\
\text { RES31 }\end{array}$} & -2.2252 & -2.7936 & -2.2839 & \multicolumn{5}{|c|}{$1985-1997$} \\
\hline & -2.2789 & -2.8361 & -2.2479 & \multirow{4}{*}{$\begin{array}{l}\text { RES34 } \\
\text { RES34 } \\
\text { RES34 }\end{array}$} & -1.3382 & -1.4095 & -1.3407 & \\
\hline & -2.6317 & -3.1671 & -2.2749 & & -1.7062 & -1.6750 & -1.7311 & \\
\hline & t-adf & & & & -1.5440 & -1.4807 & -1.6605 & \\
\hline & -1997: bar & ining vario & ables added ${ }^{\mathrm{b}}$ & & $\lambda$-max & $95 \%$ & Trace & $95 \%$ \\
\hline RES31 & -2.8864 & & & 1985 & 35-1997: bal & gaining $v a$ & riables addc & \\
\hline RES31 & $-4.2126^{* *}$ & & & $\mathrm{p}=0$ & $73.1^{* *}$ & 21.0 & 95.88 & 29.7 \\
\hline RES31 & $-3.6730^{* *}$ & & & $\mathrm{p} \leq 1$ & 13.95 & 14.1 & $22.78^{* *}$ & 15.4 \\
\hline Industry & : Textiles a & & & $\mathrm{p} \leq 2$ & .818 & 3.8 & 8.828 & 3.8 \\
\hline & t-adf & & & Industry 3 & 35: Chemic & & & \\
\hline & & $5-1984^{c}$ & & $\begin{array}{l}\mathrm{H}_{0}: \\
\text { Rank }=\mathrm{p}\end{array}$ & p $\lambda$-max & $95 \%$ & Trace & $95 \%$ \\
\hline $\begin{array}{l}\text { RES32 } \\
\text { RES32 }\end{array}$ & $\begin{array}{l}-3.8745^{*} \\
-4.4456^{*}\end{array}$ & & & & & $975-1984$ & & \\
\hline RES32 & $-4.9328^{* *}$ & & & $\mathrm{p}=0$ & $21.45^{*}$ & 21.0 & 25.64 & 29.7 \\
\hline & M1 & M2 & M3 & $\begin{array}{l}\mathrm{p} \leq 1 \\
\mathrm{p} \leq 2\end{array}$ & $\begin{array}{l}7.315 \\
0.8738\end{array}$ & $\begin{array}{r}14.1 \\
3.8\end{array}$ & $\begin{array}{l}8.189 \\
0.8738\end{array}$ & $\begin{array}{c}15.4 \\
3.8\end{array}$ \\
\hline & $($ ll-dul $)$ & & & & & & & \\
\hline & & 35-1997 & & & (t-adf) & (t-adf) & (t-adf) & \\
\hline $\begin{array}{l}\text { RES32 } \\
\text { RES32 }\end{array}$ & $\begin{array}{l}-3.1211^{*} \\
-2.8752\end{array}$ & $\begin{array}{l}-3.2543 \\
-3.1210\end{array}$ & $\begin{array}{l}-3.0265 \\
-2.7955\end{array}$ & & 1 & $985-1997$ & & \\
\hline RES32 & -2.9059 & -3.1968 & -2.8656 & RES35 & -1.9685 & -3.1844 & -3.1820 & \\
\hline & t-adf & & & $\begin{array}{l}\text { RES35 } \\
\text { RES35 }\end{array}$ & $\begin{array}{l}-1.8963 \\
-2.2876\end{array}$ & $\begin{array}{l}-3.2570 \\
-3.4259\end{array}$ & $\begin{array}{l}-3.2627 \\
-3.2335\end{array}$ & \\
\hline 19 & -1997: bar & ining varia & ables added ${ }^{\mathrm{b}}$ & & t-adf & & & \\
\hline RES32 & $-2.3054^{* *}$ & & & & & & & \\
\hline RES32 & $-3.0523^{*}$ & & & 1985 & 5-1997: bar & aining var & iables adde & \\
\hline RES32 & $-3.5752^{* *}$ & & & RES35 & $-3.1295^{*}$ & & & \\
\hline & & & & RES35 & $-2.9980^{*}$ & & & \\
\hline & & & & RES35 & $-2.9394 *$ & & & \\
\hline
\end{tabular}




\begin{tabular}{|c|c|c|c|c|c|c|c|}
\hline \multicolumn{4}{|c|}{ Industry 36: Nonmetallic minerals } & \multicolumn{4}{|c|}{ Industry 38: Metal products } \\
\hline Residual & t-adf & & & Residual & t-adf & & \\
\hline \multicolumn{4}{|c|}{$1975-1984^{\mathrm{a}}$} & \multicolumn{4}{|c|}{$1975-1984^{\mathrm{a}}$} \\
\hline RES36 & -2.7816 & & & RES38 & -2.2774 & & \\
\hline RES36 & -2.6459 & & & RES38 & -2.8069 & & \\
\hline \multirow[t]{2}{*}{ RES36 } & $-4.7583^{* *}$ & & & RES38 & $-3.2082^{*}$ & & \\
\hline & $\begin{array}{c}\text { M1 } \\
\text { (t-adf) }\end{array}$ & $\begin{array}{c}\text { M2 } \\
\text { (t-adf) }\end{array}$ & $\begin{array}{c}\text { M3 } \\
\text { (t-adf) }\end{array}$ & & $\begin{array}{c}\text { M1 } \\
\text { (t-adf) }\end{array}$ & $\begin{array}{c}\text { M2 } \\
\text { (t-adf) }\end{array}$ & $\begin{array}{c}\text { M3 } \\
\text { (t-adf) }\end{array}$ \\
\hline \multicolumn{4}{|c|}{$1985-1997$} & \multicolumn{4}{|c|}{$1985-1997$} \\
\hline RES36 & -2.1903 & -2.1938 & -1.8111 & RES38 & -1.7686 & -1.4230 & -1.6327 \\
\hline RES36 & -2.6522 & -2.5122 & -2.2906 & RES38 & -2.7850 & -2.6151 & -2.3922 \\
\hline \multirow[t]{2}{*}{ RES36 } & $-3.1145^{*}$ & -2.9676 & -2.7709 & \multirow[t]{2}{*}{ RES38 } & $-3.0954^{*}$ & -2.9954 & -2.6557 \\
\hline & t-adf & & & & t-adf & & \\
\hline \multicolumn{4}{|c|}{ 1985-1997: bargaining variables added ${ }^{\mathrm{d}}$} & \multicolumn{4}{|c|}{ 1985-1997: bargaining variables added } \\
\hline RES36 & -2.6123 & & & RES38 & -2.7060 & & \\
\hline RES36 & -2.6298 & & & RES38 & $-3.3316^{*}$ & & \\
\hline RES36 & $-3.2504^{*}$ & & & RES38 & -4.4244 & & \\
\hline
\end{tabular}

Notes: RES $j$ are the residuals of the static regression of employment on output and real labor costs for industry $j$. In 1975-1984 and 1985-1997, the regression was done by OLS. When bargaining variables are added, the residual refers to the same model but real labor costs include bargained costs and the method of estimation is 3SLS, so that wages and output are endogenous. Variables explaining the wages are real alternative income, union density and degree of openness. For industries 31 and 35, a dummy variable with value 1 after 1992 is also included. Instruments for output are own lags and seasonals. For industry 34, results using Johansen method are reported. M1 refers to a model with constant; M2 includes also a trend; and M3 further includes seasonal variables. Critical values at $5 \%$ are -2.921 for M1; -3.502 for $\mathrm{M} 2$ and $\mathrm{M} 3$.

a Unit-root tests 1975 (4) to 1984 (4). Critical values: 5\% $=-2.942 ; 1 \%=-3.617$; Constant included.

${ }^{\text {b}}$ Unit-root tests 1986 (1) to 1997 (4). Critical values: 5\% $=-2.923 ; 1 \%=-3.571$; Constant included.

'Unit-root tests 1975 (4) to 1984 (4). Critical values: $5 \%=-3.535 ; 1 \%=-4.224$; Constant and Trend included.

${ }^{d}$ Unit-root tests 1986 (1) to 1997 (4). Critical values: 5\% $=-2.923 ; 1 \%=-3.568$; Constant included.

**Significant at the 99 percent level.

*Significant at the 95 percent level. 
Nesting the Models: Manufacturing Industries, 1975-1997

\begin{tabular}{|c|c|c|c|c|}
\hline Variable & Coefficient & Standard Error & $t$-value & $t$-prob \\
\hline \multicolumn{5}{|c|}{ Equation 1 for LBLUES } \\
\hline DUMMY75 & 1.5171 & 0.16578 & 9.151 & 0.0000 \\
\hline DUMMY85 & 1.2348 & 0.18315 & 6.742 & 0.0000 \\
\hline DUMMY93 & -0.042049 & 0.011321 & -3.714 & 0.0002 \\
\hline Ind3175 & -0.051645 & 0.023671 & -2.182 & 0.0296 \\
\hline Ind3275 & 0.043068 & 0.018266 & 2.358 & 0.0188 \\
\hline Ind3475 & 0.029696 & 0.020280 & 1.464 & 0.1437 \\
\hline Ind3575 & -0.11854 & 0.017924 & -6.613 & 0.0000 \\
\hline Ind 3675 & -0.044275 & 0.017602 & -2.515 & 0.0122 \\
\hline Ind3185 & 0.058061 & 0.024076 & 2.412 & 0.0162 \\
\hline Ind 3285 & 0.070982 & 0.017312 & 4.100 & 0.0000 \\
\hline Ind 3485 & -0.042266 & 0.016816 & -2.513 & 0.0123 \\
\hline Ind3585 & -0.064253 & 0.020555 & -3.126 & 0.0019 \\
\hline Ind 3685 & -0.051673 & 0.021734 & -2.378 & 0.0178 \\
\hline Qr175 & -0.014015 & 0.0092678 & -1.512 & 0.1311 \\
\hline Qr275 & 0.0078926 & 0.0089734 & 0.880 & 0.3795 \\
\hline Qr375 & -0.013270 & 0.0090311 & -1.469 & 0.1423 \\
\hline Qr185 & 0.0028249 & 0.0085712 & 0.330 & 0.7418 \\
\hline Qr285 & 0.0093799 & 0.008029 & 1.168 & 0.2433 \\
\hline Qr385 & -0.017306 & 0.007874 & -2.198 & 0.0284 \\
\hline Q75 & 0.10918 & 0.017011 & 6.418 & 0.0000 \\
\hline Q85 & 0.061004 & 0.017210 & 3.535 & 0.0004 \\
\hline W5 & -0.10453 & 0.015246 & -6.856 & 0.0000 \\
\hline W85 & -0.029461 & 0.017607 & -1.673 & 0.0949 \\
\hline N75_1 & 0.87269 & 0.017045 & 51.198 & 0.0000 \\
\hline N85_1 & 0.87360 & 0.016696 & 52.323 & 0.0000 \\
\hline \multicolumn{5}{|c|}{ Isigma $=0.0490045$} \\
\hline \multicolumn{5}{|c|}{ Equation 2 for $W 5$} \\
\hline DUMMY85 & -0.25003 & 0.090993 & -2.748 & 0.0062 \\
\hline DUMMY93 & 0.17669 & 0.029745 & 5.940 & 0.0000 \\
\hline Qr185 & -0.0016989 & 0.0088961 & -0.191 & 0.8486 \\
\hline Qr285 & -0.0053882 & 0.0085706 & -0.629 & 0.5298 \\
\hline Qr385 & 0.0015368 & 0.0084766 & 0.181 & 0.8562 \\
\hline AW85 & 1.1983 & 0.025099 & 47.742 & 0.0000 \\
\hline UNION & 0.23724 & 0.014423 & 16.449 & 0.0000 \\
\hline UNION93 & -0.37267 & 0.070938 & -5.253 & 0.0000 \\
\hline UN3193 & 0.11571 & 0.074984 & 1.543 & 0.1234 \\
\hline UN3293 & -0.25977 & 0.075826 & -3.426 & 0.0007 \\
\hline UN3493 & -0.033919 & 0.067072 & -0.506 & 0.6133 \\
\hline UN3593 & 0.33136 & 0.058549 & 5.659 & 0.0000 \\
\hline UN3693 & -1.6041 & 0.25859 & -6.203 & 0.0000 \\
\hline
\end{tabular}


(continued)

\begin{tabular}{lccrr}
\hline Variable & Coefficient & Standard Error & $t$-value & $t$-prob \\
\hline OPEN85 & -0.044855 & 0.0089277 & -5.024 & 0.0000 \\
W85_1 & 0.0088766 & 0.0053193 & 1.669 & 0.0958 \\
$\mid$ sigma $=0.0528143$ & & & \\
loglik $=3,274.5936$ & $\log ||$ Omega $\mid=-11.9948$ & \\
$\mid$ |Omega $\mid=6.17595 \mathrm{e}-006 \quad \mathrm{~T}=546$ & & \\
LR test of over-identifying restrictions: $\chi^{2}(28)=249.677[0.0000]^{* *}$ & & \\
\hline
\end{tabular}

Notes: $N$ is number of production workers; $W$ is the real labor cost of a production worker; $Q$ is production; AW is the alternative wage; UNION is union density; OPEN is the degree of openness; Qr $j$ is a dummy variable for quarter $j$; Ind. $i$ is a dummy variable for industry $i$. Industries included are: food, beverage, and tobacco (31); textiles and apparel (32); paper (34); chemicals (35); nonmetallic minerals (36); and metal products (38). "_1" attached to a variable indicates the variable is lagged one period. Variables with " 75 " have the actual values from 1975 up to 1984 and zero elsewhere. Those ending in " 85 " have a value of zero in 1975-1984 and the actual value from that date on. DUMMY75 is a dummy variable equal to 1 in 1975-1984; DUMMY85 is a dummy variable equal to 1 in 1985-1997; DUMMY93 is a dummy variable equal to 1 in 1993-1997. UNION93 is UNION multiplied by DUMMY93; $\mathrm{UN} j 93$ is UNION93 multiplied by Ind.j. The method of estimation is 3SLS. The present sample is 7 to 552 .

Tests of hypothesis: (1) $Q 75=Q 85: \& 19-\& 20=0$; Wald test for general restrictions: Gen$\operatorname{Res} \chi^{2}(1)=4.6104[0.0318]^{*}$.

(2) $W 75=W 85: \& 21-\& 22=0$; Wald test for general restrictions: GenRes $\chi^{2}(1)=10.469$ $[0.0012]^{* *}$.

(3) $L A G G E D N 75=L A G G E D$ N85: \&23-\&24 = 0; Wald test for general restrictions: Gen$\operatorname{Res} \chi^{2}(1)=0.15229[0.6964]$.

\section{References}

Aghion, P., and G. Saint-Paul. 1993. Uncovering some causal relationships between productivity growth and the structure of economic fluctuations: A tentative survey. NBER Working Paper no. 4603. Cambridge, Mass.: National Bureau of Economic Research, December.

Allen, S. 1986. Union work rules and efficiency in the building trades. Journal of Labor Economics 4 (2): 212-42.

-1988. Unions and job security in the public sector. In When public sector workers unionize, ed. R. B. Freeman and C. Ichniowski, 271-96. Chicago: University of Chicago Press.

Allen, S., A. Cassoni, and G. J. Labadie. 1994. Labor market flexibility and unemployment in Chile and Uruguay. Estudios de Economía 21 (special number): 129-46.

1996. Wages and employment after reunionization in Uruguay. Cuadernos de Economía 33 (99): 277-39.

Banerjee, A., J. Dolado, D. Hendry, and J. W. Galbraith. 1993. Co-integration, errorcorrection, and the econometric analysis of non-stationary data. New York: Oxford University Press.

Binmore, K., A. Rubinstein, and A. Wolinsky. 1986. The nash bargaining solution in economic modelling. Rand Journal of Economics 17:176-88. 
Blanchard, O. J., and D. Quah. 1989. The dynamic effects of aggregate demand and supply disturbances. The American Economic Review 79 (4): 655-73.

Blanchard, O. J., and L. H. Summers. 1986. Hysteresis and the European unemployment problem. In NBER macroeconomic annual 1986, ed. S. Fischer, 15-78. Cambridge, Mass.: MIT Press.

Blanchflower, D. G. 1984. Union relative wage effects: A cross-section analysis using establishment data. British Journal of Industrial Relations 22:311-32.

Blanchflower, D. G., N. Millward, and A. J. Oswald. 1991. Unionism and employment behaviour. Economic Journal 101:815-34.

Boal, W. M., and J. H. Pencavel. 1994. The effects of labor unions on employment, wages and days of operation: Coal mining in West Virginia. Quarterly Journal of Economics 109:267-98.

Booth, A. L. 1995. The economics of the trade unions. New York: Cambridge University Press.

Burgess, S. M. 1988. Employment adjustment in UK manufacturing. Economic Journal 98:81-93.

. 1989. Employment and turnover in UK manufacturing industries, 19631982. Oxford Bulletin of Economics and Statistics 51 (2): 163-92.

Burgess, S. M., and J. Dolado. 1989. Intertemporal rules with variable speed of adjustment: An application to UK manufacturing employment. Economic Journal 99:347-365.

Carruth, A., and A. Oswald. 1987. On union preferences and labour market models: Insiders and outsiders. Economic Journal 97:431-45.

Cassoni, A., and Z. Ferre. 1997. Costos no salariales en el mercado de trabajo del Uruguay. [Nonwage costs in the Uruguayan labor market]. Working Paper no. 8/ 97. Montevideo, Uruguay: Departamento de Economía, Facultad de Ciencias Sociales, Universidad de la República.

Cassoni, A., G. J. Labadie, and S. Allen. 1995. Uruguay. In Reforming the labor market in a liberalized economy, ed. G. Márquez, 137-91. Washington, D.C.: InterAmerican Development Bank, Centers for Research in Applied Economics.

Cedrola, G., J. Raso, and F. Perez Tabó. 1998. La negociación colectiva en el Uruguay, 1996-1997. Santiago, Chile: I.L.O., forthcoming.

de Brun, J., and G. J. Labadie. 1997. Mercado laboral, apertura y recesión: La experiencia uruguaya de los noventa. [Labor market, openness, and economic crisis: The Uruguayan experience in the nineties]. In Mercados laborales en los 90: Cinco ejemplos de América Latina, ed. CIEDLA, 283-353. Buenos Aires, Argentina: Konrad Adenauer Stiftung.

de Menil, G. 1971. Bargaining: Monopoly power versus union power. Cambridge, Mass.: MIT Press.

Edwards, S. 1995. Crisis and reform in Latin America. New York: Oxford University Press.

Engle, R. F., and C. W. J. Granger. 1987. Cointegration and error correction: Representation, estimation and testing. Econometrica 55:251-76.

Favaro, E., and C. Sapelli. 1986. Shocks externos, Grado de apertura y politica doméstica. [External shocks, degree of openness, and domestic economic policy]. Montevideo, Uruguay: Banco Central del Uruguay.

Freeman, R. 1980. The exit-voice tradeoff in the labor market: Unionism, job tenure, quits, and separations. Quarterly Journal of Economics 94 (4): 643-74.

Freeman, R., and J. L. Medoff. 1982. Substitution between production labor and other inputs in unionized and nonunionized manufacturing. Review of Economics and Statistics 64 (2): 220-33. . 1984. What do unions do? New York: Basic Books. 
Fuller, W. A. 1976. Introduction to statistical time series. New York: John Wiley and Sons.

Gillespie, C. G. 1991. Negotiating democracy. Cambridge, U.K.: Cambridge University Press.

Hamermesh, D. S. 1993. Labor demand. Princeton, N.J.: Princeton University Press.

1995. Labour demand and the source of adjustment costs. The Economic Journal 105:620-34.

Hamermesh, D. S., and G. A. Pfann. 1996. Adjustment costs in factor demand. Journal of Economic Literature 34 (3): 1264-92.

Handelman, H. 1981. Labor-industrial conflict and the collapse of Uruguayan democracy. Journal of Interamerican Studies and World Affairs 28 (4): 371-94.

Hausman, J. A. 1978. Specification tests in econometrics. Econometrica 46: 1251-71.

Hirsch, B. T., and J. T. Addison. 1986. The economic analysis of unions: New approaches and evidence. Boston: Allen and Unwin.

Layard, R., S. Nickell, and R. Jackman. 1991. Unemployment: Macroeconomic performance and the labor market. New York: Oxford University Press.

Lewis, H. G. 1986. Union relative wage effects: A survey. Chicago: University of Chicago Press.

. 1990. Union/nonunion wage gaps in the public sector. Journal of Labour Economics 8 (1): S260-S328.

Lockwood, B., and A. Manning. 1989. Dynamic wage-employment bargaining with employment adjustment costs. Economic Journal 99:1143-58.

Machin, S., and S. Wadhwani. 1991. The effects of unions on organisational change and employment. Economic Journal 101:835-54.

Medoff, J. L. 1979. Layoffs and alternatives under trade unions in U.S. manufacturing. American Economic Review 69 (3): 380-95.

Pencavel, J. 1991. Labor markets under trade unionism: Employment, wages and hours. London: Basil Blackwell.

Picardo, S., C. Daude, and Z. Ferre. 1997. Indice del costo de la mano de obra: 1982-1995. [Index of labor costs: 1982-1995]. Working Paper no. 1/97. Montevideo, Uruguay: Universidad de la República, Departamento de Economía, Facultad de Ciencias Sociales.

Rama, M. 1993a. Organized labor and the political economy of product market distortions. Washington, D.C.: World Bank/CINVE.

1993b. Institucionalidad laboral y crecimiento económico en el Uruguay. Academia Nacional de Economía. Mimeograph.

1994. Bargaining structure and economic performance in the open economy. European Economic Review 38:403-15.

Spanos, A. 1986. Statistical foundations of econometric modelling. New York: Cambridge University Press.

White, H. 1980. A heteroskedasticity-consistent covariance matrix estimator and a direct test for heteroskedasticity. Econometrica 48:817-38. 
